\title{
Comparative Proteomic Analysis of Wild Type and Mutant Lacking a SCF E3 Ligase F-box Protein in Magnaporthe oryzae
}

\author{
Jaclyn Gowen Kalmar'1, Yeonyee Oh",3, Ralph A. Dean²,3, David C. Muddiman 1,4,5* \\ ${ }^{1}$ FTMS Laboratory for Human Health Research, Department of Chemistry, ${ }^{2}$ Department of \\ Plant Pathology, ${ }^{3}$ Center for Integrated Fungal Research, ${ }^{4}$ Molecular Education, Technology, \\ and Research Innovation Center (METRIC), ${ }^{5}$ Department of Plant and Microbial Biology, North \\ Carolina State University, Raleigh, NC 27695
}

\section{TABLE OF CONTENTS}

Supplemental Figure 1. Unnormalized spectral counting scatterplots

Supplemental Table 1. Proteins with increased abundance in the E3 Ligase KO samples

Supplemental Table 2. Proteins with decreased abundance in the E3 Ligase KO samples

Supplemental Table 3. Proteins unique to the WT samples

Supplemental Table 4. Proteins unique to the E3 Ligase KO samples

Supplemental Table 5. Post-translational modification sites

Supplemental Table 6. List of hypothetical proteins with Pfam annotation 
A

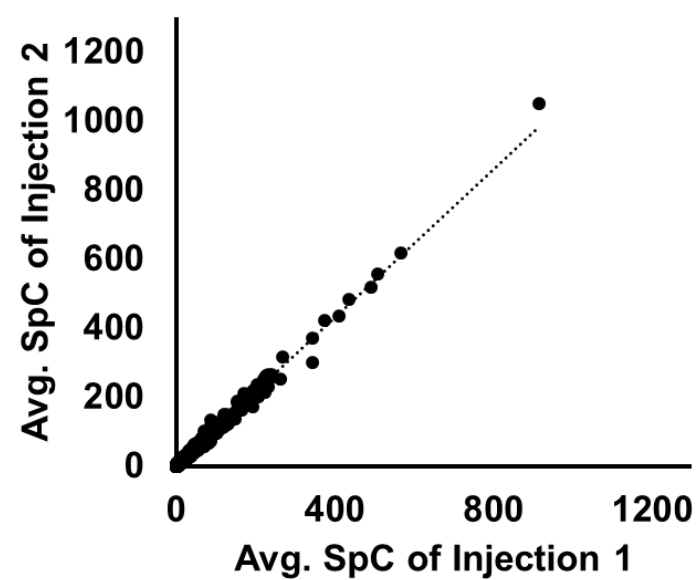

$r=0.996$

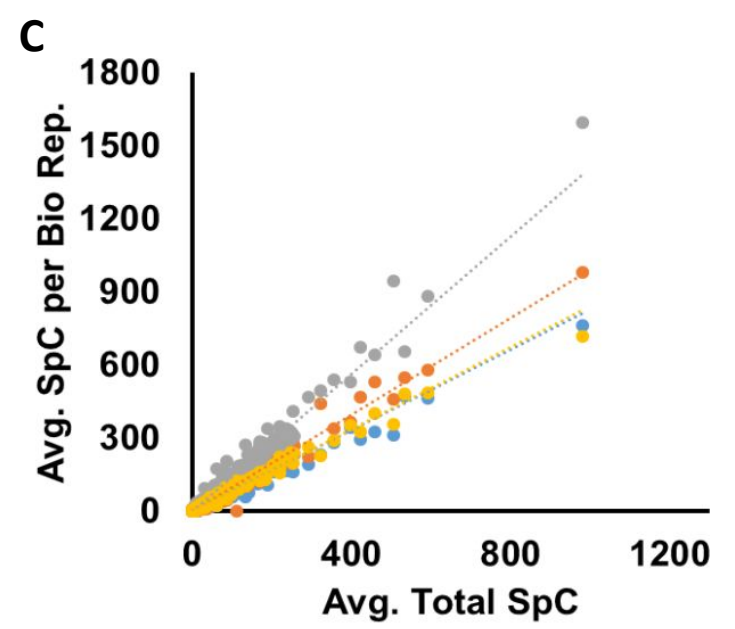

$$
\begin{array}{ll|ll}
1 & r=0.985 & 2 & r=0.989 \\
3 & r=0.984 & 4 & r=0.992
\end{array}
$$

B

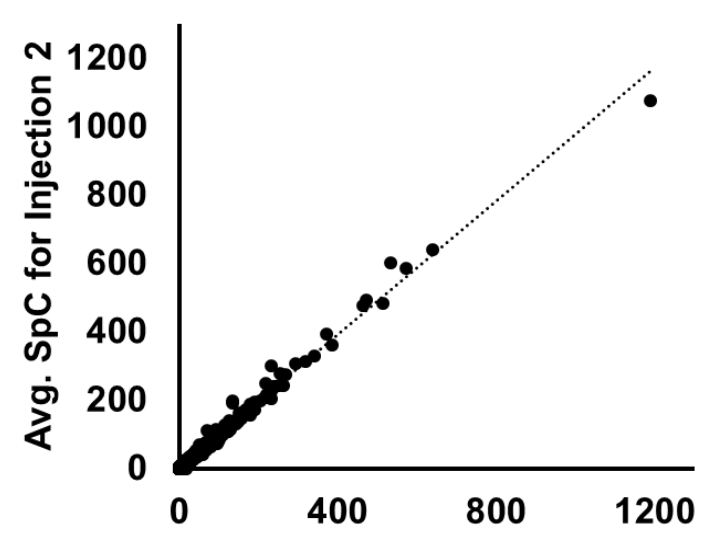

Avg. SpC of Injection 1

$$
r=0.995
$$

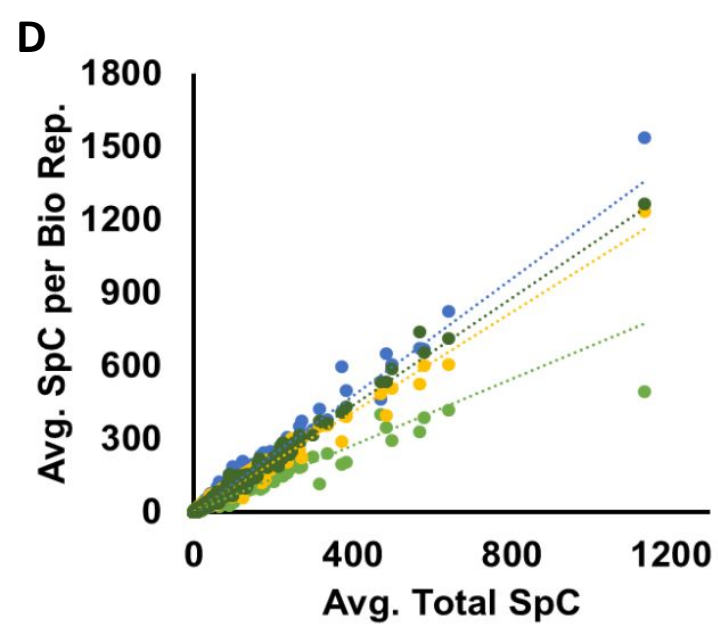

$$
1 r=0.964 \quad 2 \quad r=0.987
$$

$3 r=0.990 \quad 4 \quad r=0.993$

Supplemental Figure 1. Unnormalized spectral counting scatterplots of (A) WT and (B) E3 ligase $\mathrm{KO}$ technical replicates. To get an accurate comparison of each injection, the average unnormalized spectral counts for all first technical replicates were plotted against the average unnormalized spectral counts for all second technical replicates per protein. The WT and E3 ligase KO biological replicates were then compared first for the (C) WT samples as shown and then for the (D) E3 ligase KO samples. The average number of unnormalized spectral counts per protein in a biological sample was plotted against the average total number of spectral counts across all biological samples. 
Supplemental Table 1. Proteins with increased abundance in the E3 Ligase Knock out samples.

\begin{tabular}{|c|c|c|c|c|}
\hline Accession & Description & $\begin{array}{l}\text { Total } \\
\text { NSpC }\end{array}$ & $\begin{array}{c}\text { Fold } \\
\text { Change }\end{array}$ & $p$-value \\
\hline MGG_01364T0U & $\begin{array}{c}\text { MGG_01364 | Magnaporthe oryzae 70-15 } \\
\text { hypothetical protein (1012 aa) }\end{array}$ & 85.4015 & 2.4748 & 0.0042 \\
\hline MGG_02398T0U & $\begin{array}{l}\text { MGG_02398 | Magnaporthe oryzae } 70-15 \\
\text { DENN domain-containing protein (906 aa) }\end{array}$ & 195.1320 & 4.2133 & 0.0006 \\
\hline MGG_03223T0U & $\begin{array}{c}\text { MGG_03223 | Magnaporthe oryzae 70-15 } \\
\text { hypothetical protein (2138 aa) }\end{array}$ & 79.6347 & 2.0121 & 0.0275 \\
\hline MGG_05937T0U & $\begin{array}{c}\text { MGG_05937 | Magnaporthe oryzae 70-15 } \\
\text { dynamin family protein (970 aa) }\end{array}$ & 13.3350 & 11.7463 & 0.0203 \\
\hline MGG_05981T0U & $\begin{array}{c}\text { MGG_05981 | Magnaporthe oryzae } 70-15 \\
\text { glutamine amidotransferase subunit pdxT } \\
\text { (247 aa) }\end{array}$ & 146.4937 & 2.3061 & 0.0001 \\
\hline MGG_06026T0U & $\begin{array}{c}\text { MGG_06026 | Magnaporthe oryzae 70-15 } \\
\text { hypothetical protein (635 aa) }\end{array}$ & 61.9409 & 2.4578 & 0.0087 \\
\hline MGG_08290T0U & $\begin{array}{c}\text { MGG_08290 | Magnaporthe oryzae 70-15 } \\
\text { hypothetical protein (428 aa) }\end{array}$ & 18.9516 & 6.4538 & 0.0103 \\
\hline MGG_09215T0U & $\begin{array}{c}\text { MGG_09215 | Magnaporthe oryzae 70-15 } \\
\text { hypothetical protein (1677 aa) }\end{array}$ & 33.4047 & 2.4569 & 0.0469 \\
\hline MGG_12004T0U & $\begin{array}{c}\text { MGG_12004 | Magnaporthe oryzae 70-15 } \\
\text { C2HC5 finger protein (552 aa) }\end{array}$ & 50.4159 & 2.0109 & 0.0451 \\
\hline MGG_02701T0P & $\begin{array}{c}\text { MGG_02701 | Magnaporthe oryzae 70-15 } \\
\text { hypothetical protein (1113 aa) }\end{array}$ & 44.1878 & 2.5453 & 0.0351 \\
\hline MGG_06404T0P & $\begin{array}{c}\text { MGG_06404 | Magnaporthe oryzae 70-15 } \\
\text { hypothetical protein (399 aa) }\end{array}$ & 39.0019 & 2.5126 & 0.0059 \\
\hline MGG_07222T0P & $\begin{array}{l}\text { MGG_07222 | Magnaporthe oryzae 70-15 } \\
\text { DNA polymerase epsilon subunit B ( } 866 \text { aa) }\end{array}$ & 11.3636 & 9.8619 & 0.0363 \\
\hline MGG_08267T0P & $\begin{array}{c}\text { MGG_08267 | Magnaporthe oryzae 70-15 } \\
\text { hypothetical protein (541 aa) }\end{array}$ & 58.1117 & 3.6401 & 0.0042 \\
\hline MGG_09394T0P & $\begin{array}{c}\text { MGG_09394 | Magnaporthe oryzae 70-15 } \\
\text { hypothetical protein (350 aa) }\end{array}$ & 44.5931 & 2.8984 & 0.0379 \\
\hline MGG_09838T0P & $\begin{array}{c}\text { MGG_09838 | Magnaporthe oryzae 70-15 } \\
\text { sulfate transporter } 4.1 \text { (801 aa) }\end{array}$ & 76.1882 & 3.3363 & 0.0195 \\
\hline MGG_11100T0P & $\begin{array}{c}\text { MGG_11100 | Magnaporthe oryzae 70-15 } \\
\text { hypothetical protein (656 aa) }\end{array}$ & 14.5478 & 4.7794 & 0.0220 \\
\hline MGG_11899T0P & $\begin{array}{l}\text { MGG_11899 | Magnaporthe oryzae 70-15 } \\
\text { SH3 domain-containing protein (1013 aa) }\end{array}$ & 47.5260 & 2.6763 & 0.0328 \\
\hline MGG_03192T0UP & $\begin{array}{c}\text { MGG_03192 | Magnaporthe oryzae } 70-15 \\
\text { RNA polymerase II transcription factor B } \\
\text { subunit } 1 \text { ( } 654 \mathrm{aa})\end{array}$ & 77.5580 & 2.0489 & 0.0304 \\
\hline MGG_03286T0UP & $\begin{array}{c}\text { MGG_03286 | Magnaporthe oryzae 70-15 } \\
\text { hypothetical protein (1175 aa) }\end{array}$ & 70.2955 & 7.7137 & 0.0008 \\
\hline MGG_00583T0 & $\begin{array}{c}\text { MGG_00583 | Magnaporthe oryzae 70-15 } \\
\text { beta-galactosidase (1072 aa) }\end{array}$ & 10.3781 & 9.1663 & 0.0010 \\
\hline MGG_00602T0 & $\begin{array}{l}\text { MGG_00602 | Magnaporthe oryzae 70-15 } \\
\text { cross-pathway control protein } 1 \text { ( } 240 \text { aa) }\end{array}$ & 40.0262 & 16.1631 & 0.0002 \\
\hline MGG_00669T0 & $\begin{array}{l}\text { MGG_00669 | Magnaporthe oryzae 70-15 } \\
\text { hypothetical protein (555 aa) }\end{array}$ & 22.1006 & 3.1110 & 0.0331 \\
\hline MGG_00859T0 & $\begin{array}{c}\text { MGG_00859 | Magnaporthe oryzae 70-15 } \\
\text { ariadne-1 (523 aa) }\end{array}$ & 52.1920 & 4.5748 & 0.0002 \\
\hline MGG_01174T0 & $\begin{array}{c}\text { MGG_01174 | Magnaporthe oryzae 70-15 } \\
\text { hypothetical protein (527 aa) }\end{array}$ & 19.0049 & 4.3647 & 0.0150 \\
\hline
\end{tabular}




\begin{tabular}{|c|c|c|c|c|}
\hline MGG_01381T0 & $\begin{array}{l}\text { MGG_01381 | Magnaporthe oryzae 70-15 } \\
\text { calcium permease (1159 aa) }\end{array}$ & 15.2448 & 6.4668 & 0.0124 \\
\hline MGG_01665T0 & $\begin{array}{c}\text { MGG_01665 | Magnaporthe oryzae } 70-15 \\
\text { hypothetical protein (411 aa) }\end{array}$ & 12.6940 & 3.9657 & 0.0358 \\
\hline MGG_01823T0 & $\begin{array}{c}\text { MGG_01823 | Magnaporthe oryzae } 70-15 \\
\text { LAlv9 family protein (812 aa) }\end{array}$ & 22.2452 & 2.3804 & 0.0467 \\
\hline MGG_02123T0 & $\begin{array}{c}\text { MGG_02123 | Magnaporthe oryzae 70-15 } \\
\text { hypothetical protein (747 aa) }\end{array}$ & 8.2274 & 7.0595 & 0.0070 \\
\hline MGG_02459T0 & $\begin{array}{c}\text { MGG_02459 | Magnaporthe oryzae } 70-15 \\
\text { DNA polymerase delta small subunit (498 aa) }\end{array}$ & 18.1937 & 4.4982 & 0.0001 \\
\hline MGG_02891T0 & $\begin{array}{c}\text { MGG_02891 | Magnaporthe oryzae 70-15 } \\
\text { SH3 domain signaling protein (493 aa) }\end{array}$ & 55.7704 & 2.1981 & 0.0045 \\
\hline MGG_02992T0 & $\begin{array}{c}\text { MGG_02992 | Magnaporthe oryzae 70-15 } \\
\text { hypothetical protein (605 aa) }\end{array}$ & 9.9156 & 8.9156 & 0.0097 \\
\hline MGG_03150T0 & $\begin{array}{c}\text { MGG_03150 | Magnaporthe oryzae } 70-15 \\
\text { cytosolic iron-sulfur protein assembly protein } \\
1(447 \mathrm{aa})\end{array}$ & 47.9875 & 2.2313 & 0.0354 \\
\hline MGG_03292T0 & $\begin{array}{c}\text { MGG_03292 | Magnaporthe oryzae 70-15 } \\
\text { hypothetical protein (795 aa) }\end{array}$ & 30.8299 & 3.4458 & 0.0038 \\
\hline MGG_03321T0 & $\begin{array}{c}\text { MGG_03321 | Magnaporthe oryzae 70-15 } \\
\text { hypothetical protein (432 aa) }\end{array}$ & 25.7635 & 2.6236 & 0.0191 \\
\hline MGG_03416T0 & $\begin{array}{c}\text { MGG_03416 | Magnaporthe oryzae 70-15 } \\
\text { acetyltransferase (201 aa) }\end{array}$ & 148.3183 & 2.2084 & 0.0038 \\
\hline MGG_03558T0 & $\begin{array}{c}\text { MGG_03558 | Magnaporthe oryzae 70-15 PH } \\
\text { domain-containing protein (932 aa) }\end{array}$ & 18.6657 & 3.0935 & 0.0361 \\
\hline MGG_03569T0 & $\begin{array}{c}\text { MGG_03569 | Magnaporthe oryzae 70-15 } \\
\text { fatty acid desaturase (569 aa) }\end{array}$ & 56.3258 & 4.1761 & 0.0004 \\
\hline MGG_03900T0 & $\begin{array}{l}\text { MGG_03900 | Magnaporthe oryzae 70-15 } \\
\text { aldehyde dehydrogenase (497 aa) }\end{array}$ & 331.3938 & 2.0286 & 0.0054 \\
\hline MGG_04107T0 & $\begin{array}{l}\text { MGG_04107 | Magnaporthe oryzae 70-15 } \\
\text { SET domain-containing protein } 8 \text { (479 aa) }\end{array}$ & 15.7002 & 2.6606 & 0.0427 \\
\hline MGG_04146T0 & $\begin{array}{c}\text { MGG_04146 | Magnaporthe oryzae } 70-15 \\
\text { hypothetical protein }(675 \mathrm{aa})\end{array}$ & 10.6710 & 3.6636 & 0.0344 \\
\hline MGG_04327T0 & $\begin{array}{c}\text { MGG_04327 | Magnaporthe oryzae } 70-15 \\
\text { hypothetical protein (1241 aa) }\end{array}$ & 9.5873 & 8.1641 & 0.0303 \\
\hline MGG_04398T0 & $\begin{array}{l}\text { MGG_04398 | Magnaporthe oryzae } 70-15 \text { 6- } \\
\text { phosphogluconate dehydrogenase (334 aa) }\end{array}$ & 42.1599 & 2.0394 & 0.0327 \\
\hline MGG_04469T0 & $\begin{array}{l}\text { MGG_04469 | Magnaporthe oryzae 70-15 } \\
\text { cytochrome P450 97B3 (603 aa) }\end{array}$ & 15.2408 & 4.9209 & 0.0036 \\
\hline MGG_04843T0 & $\begin{array}{c}\text { MGG_04843 | Magnaporthe oryzae } 70-15 \\
\text { hypothetical protein }(611 \mathrm{aa})\end{array}$ & 19.4048 & 2.4866 & 0.0293 \\
\hline MGG_05178T0 & $\begin{array}{l}\text { MGG_05178 | Magnaporthe oryzae 70-15 AF- } \\
9(264 \text { aa) }\end{array}$ & 9.6411 & 6.4974 & 0.0461 \\
\hline MGG_05256T0 & $\begin{array}{c}\text { MGG_05256 | Magnaporthe oryzae 70-15 } \\
\text { vacuolar protein sorting-associated protein } \\
(830 \mathrm{aa})\end{array}$ & 31.8244 & 2.1065 & 0.0486 \\
\hline MGG_05284T0 & $\begin{array}{c}\text { MGG_05284 | Magnaporthe oryzae 70-15 } \\
\text { cytosolic regulator Pianissimo (1397 aa) }\end{array}$ & 11.4356 & 7.8929 & 0.0273 \\
\hline MGG_06799T0 & $\begin{array}{c}\text { MGG_06799 | Magnaporthe oryzae 70-15 } \\
\text { hypothetical protein (796 aa) }\end{array}$ & 32.0775 & 7.3486 & 0.0192 \\
\hline MGG_06925T0 & $\begin{array}{c}\text { MGG_06925 | Magnaporthe oryzae 70-15 } \\
\text { hypothetical protein (1337 aa) }\end{array}$ & 18.8051 & 2.6881 & 0.0244 \\
\hline MGG_07307T0 & $\begin{array}{l}\text { MGG_07307 | Magnaporthe oryzae 70-15 } \\
\text { NADH-cytochrome b5 reductase } 2 \text { ( } 309 \text { aa) }\end{array}$ & 85.7192 & 3.2424 & 0.0157 \\
\hline MGG_07573T0 & $\begin{array}{c}\text { MGG_07573 | Magnaporthe oryzae 70-15 } \\
\text { hypothetical protein (1060 aa) }\end{array}$ & 12.5164 & 5.1170 & 0.0231 \\
\hline MGG_07890T0 & $\begin{array}{l}\text { MGG_07890 | Magnaporthe oryzae 70-15 } \\
\text { aldehyde dehydrogenase } 3 / 1 \text { (528 aa) }\end{array}$ & 44.8820 & 2.8234 & 0.0104 \\
\hline
\end{tabular}




\begin{tabular}{|c|c|c|c|c|}
\hline MGG_07981T0 & $\begin{array}{c}\text { MGG_07981 | Magnaporthe oryzae 70-15 } \\
\text { aminopeptidase ypdF (492 aa) }\end{array}$ & 23.3258 & 2.7871 & 0.0061 \\
\hline MGG_08114T0 & $\begin{array}{l}\text { MGG_08114 | Magnaporthe oryzae 70-15 } \\
\text { hypothetical protein (856 aa) }\end{array}$ & 10.1719 & 8.7228 & 0.0089 \\
\hline MGG_08156T0 & $\begin{array}{l}\text { MGG_08156 | Magnaporthe oryzae 70-15 } \\
\text { kinesin-II } 85 \text { kDa subunit (615 aa) }\end{array}$ & 11.8046 & 6.9075 & 0.0158 \\
\hline MGG_08293T0 & $\begin{array}{l}\text { MGG_08293 | Magnaporthe oryzae 70-15 } \\
\text { salicylate hydroxylase (472 aa) }\end{array}$ & 8.9223 & 7.5284 & 0.0110 \\
\hline MGG_08463T0 & $\begin{array}{l}\text { MGG_08463 | Magnaporthe oryzae 70-15 } \\
\text { transcription factor MBP1 (716 aa) }\end{array}$ & 19.4364 & 3.2068 & 0.0349 \\
\hline MGG_08615T0 & $\begin{array}{l}\text { MGG_08615 | Magnaporthe oryzae 70-15 } \\
\text { dihydrodipicolinate synthase (330 aa) }\end{array}$ & 18.6364 & 11.4839 & 0.0054 \\
\hline MGG_08841T0 & $\begin{array}{c}\text { MGG_08841 | Magnaporthe oryzae 70-15 } \\
\text { hypothetical protein (1037 aa) }\end{array}$ & 58.5108 & 3.1425 & 0.0062 \\
\hline MGG_08860T0 & $\begin{array}{c}\text { MGG_08860 | Magnaporthe oryzae 70-15 } \\
\text { exosome complex exonuclease RRP45 (294 } \\
\text { aa) }\end{array}$ & 40.2269 & 2.0543 & 0.0460 \\
\hline MGG_08914T0 & $\begin{array}{c}\text { MGG_08914 | Magnaporthe oryzae 70-15 } \\
\text { hypothetical protein (1103 aa) }\end{array}$ & 8.2271 & 5.3867 & 0.0485 \\
\hline MGG_09071T0 & $\begin{array}{c}\text { MGG_09071 | Magnaporthe oryzae } 70-15 \\
\text { aminobenzoyl-glutamate utilization protein B } \\
(410 \mathrm{aa})\end{array}$ & 78.9423 & 2.2481 & 0.0015 \\
\hline MGG_09283T0 & $\begin{array}{c}\text { MGG_09283 | Magnaporthe oryzae } 70-15 \\
\text { NEDD8-activating enzyme E1 catalytic } \\
\text { subunit (435 aa) }\end{array}$ & 34.6154 & 2.3797 & 0.0229 \\
\hline MGG_10157T0 & $\begin{array}{l}\text { MGG_10157 | Magnaporthe oryzae 70-15 } \\
\text { hypothetical protein (727 aa) }\end{array}$ & 12.8727 & 4.5804 & 0.0235 \\
\hline MGG_10189T0 & $\begin{array}{c}\text { MGG_10189 | Magnaporthe oryzae 70-15 } \\
\text { beta-glucosidase A ( } 513 \text { aa) }\end{array}$ & 57.7745 & 2.1419 & 0.0191 \\
\hline MGG_10327T0 & $\begin{array}{l}\text { MGG_10327 | Magnaporthe oryzae 70-15 } \\
\text { hypothetical protein (730 aa) }\end{array}$ & 485.4915 & 2.2794 & $8.09 \mathrm{E}-06$ \\
\hline MGG_10528T0 & $\begin{array}{c}\text { MGG_10528 | Magnaporthe oryzae } 70-15 \\
\text { zinc binuclear cluster-type protein (1032 aa) }\end{array}$ & 31.4620 & 2.3303 & 0.0060 \\
\hline MGG_10529T0 & $\begin{array}{l}\text { MGG_10529 | Magnaporthe oryzae 70-15 } \\
\text { fungal specific transcription factor domain- } \\
\text { containing protein (791 aa) }\end{array}$ & 12.5233 & 3.9032 & 0.0488 \\
\hline MGG_11322T0 & $\begin{array}{c}\text { MGG_11322 | Magnaporthe oryzae 70-15 } \\
\text { dephospho-CoA kinase (278 aa) }\end{array}$ & 40.0425 & 2.5859 & 0.0192 \\
\hline MGG_11426T0 & $\begin{array}{c}\text { MGG_11426 | Magnaporthe oryzae 70-15 5'- } \\
\text { 3' exoribonuclease } 2 \text { (1021 aa) }\end{array}$ & 132.6259 & 2.1179 & 0.0031 \\
\hline MGG_11575T0 & $\begin{array}{l}\text { MGG_11575 | Magnaporthe oryzae 70-15 } \\
\text { hypothetical protein (248 aa) }\end{array}$ & 115.0971 & 2.1933 & 0.0035 \\
\hline MGG_13058T0 & $\begin{array}{c}\text { MGG_13058 | Magnaporthe oryzae 70-15 } \\
\text { hypothetical protein (828 aa) }\end{array}$ & 75.0941 & 49.1844 & 0.0002 \\
\hline MGG_13191T0 & $\begin{array}{c}\text { MGG_13191 | Magnaporthe oryzae 70-15 } \\
\text { hypothetical protein (184 aa) }\end{array}$ & 45.0759 & 2.3589 & 0.0127 \\
\hline MGG_14266T0 & $\begin{array}{l}\text { MGG_14266 | Magnaporthe oryzae 70-15 } \\
\text { ubiquitin-conjugating enzyme (261 aa) }\end{array}$ & 38.3065 & 3.3165 & 0.0464 \\
\hline MGG_14270T0 & $\begin{array}{l}\text { MGG_14270 | Magnaporthe oryzae 70-15 } \\
\text { hypothetical protein (366 aa) }\end{array}$ & 22.4262 & 2.4033 & 0.0426 \\
\hline MGG_16442T0 & $\begin{array}{c}\text { MGG_16442 | Magnaporthe oryzae 70-15 } \\
\text { hypothetical protein (277 aa) }\end{array}$ & 18.9157 & 3.9202 & 0.0072 \\
\hline MGG_17680T0 & $\begin{array}{c}\text { MGG_17680 | Magnaporthe oryzae 70-15 } \\
\text { hypothetical protein (117 aa) }\end{array}$ & 35.6630 & 2.4375 & 0.0301 \\
\hline MGG_17699T0 & $\begin{array}{l}\text { MGG_17699 | Magnaporthe oryzae 70-15 } \\
\text { aminodeoxychorismate synthase }(879 \text { aa) }\end{array}$ & 13.9315 & 4.9680 & 0.0077 \\
\hline MGG_17701T0 & $\begin{array}{l}\text { MGG_17701 | Magnaporthe oryzae 70-15 } \\
\text { hypothetical protein (357 aa) }\end{array}$ & 12.0949 & 3.0038 & 0.0400 \\
\hline
\end{tabular}


Supplemental Table 2. Proteins with decreased abundance in the E3 Ligase knockout samples.

\begin{tabular}{|c|c|c|c|c|}
\hline Accession & Description & $\begin{array}{l}\text { Total } \\
\text { NSpC }\end{array}$ & $\begin{array}{l}\text { Fold } \\
\text { Change }\end{array}$ & $\begin{array}{c}p- \\
\text { value }\end{array}$ \\
\hline MGG_02055TOU & $\begin{array}{l}\text { MGG_02055 | Magnaporthe oryzae 70-15 } \\
\text { hypothetical protein ( } 616 \text { aa) }\end{array}$ & 52.2216 & 0.2763 & 0.0072 \\
\hline MGG_08005T0U & $\begin{array}{c}\text { MGG_08005 | Magnaporthe oryzae } 70-15 \\
\text { phosphoinositide 3-phosphate phosphatase } \\
\text { (659 aa) }\end{array}$ & 56.6775 & 0.4887 & 0.0107 \\
\hline MGG_12999T0U & $\begin{array}{c}\text { MGG_12999 | Magnaporthe oryzae 70-15 } \\
\text { acetoacetate-CoA ligase (705 aa) }\end{array}$ & 93.0919 & 0.4441 & 0.0455 \\
\hline MGG_05257T0P & $\begin{array}{c}\text { MGG_05257 | Magnaporthe oryzae 70-15 } \\
\text { RING finger protein (738 aa) }\end{array}$ & 23.1149 & 0.3088 & 0.0356 \\
\hline MGG_00070T0 & $\begin{array}{c}\text { MGG_00070 | Magnaporthe oryzae } 70-15 \\
\text { hypothetical protein (235 aa) }\end{array}$ & 10.8896 & 19.4507 & $\begin{array}{l}3.15 \mathrm{E}- \\
06\end{array}$ \\
\hline MGG_00143T0 & $\begin{array}{c}\text { MGG_00143 | Magnaporthe oryzae 70-15 } \\
\text { hypothetical protein (396 aa) }\end{array}$ & 39.1310 & 17.4952 & $\begin{array}{c}3.73 \mathrm{E}- \\
05\end{array}$ \\
\hline MGG_00504T0 & $\begin{array}{l}\text { MGG_00504 | Magnaporthe oryzae 70-15 } \\
\text { zinc finger protein } 740 \text { (676 aa) }\end{array}$ & 31.5709 & 4.7826 & 0.0001 \\
\hline MGG_00683T0 & $\begin{array}{l}\text { MGG_00683 | Magnaporthe oryzae 70-15 } \\
\text { endoplasmic oxidoreductin-1 (607 aa) }\end{array}$ & 71.1382 & 12.4125 & 0.0001 \\
\hline MGG_00835T0 & $\begin{array}{l}\text { MGG_00835 | Magnaporthe oryzae 70-15 } \\
\text { flotillin domain-containing protein (503 aa) }\end{array}$ & 15.7801 & 14.1606 & 0.0002 \\
\hline MGG_00851T0 & $\begin{array}{c}\text { MGG_00851 | Magnaporthe oryzae 70-15 } \\
\text { hypothetical protein (426 aa) }\end{array}$ & 17.7961 & 10.1686 & 0.0003 \\
\hline MGG_01069T0 & $\begin{array}{c}\text { MGG_01069 | Magnaporthe oryzae 70-15 } \\
\text { hypothetical protein (104 aa) }\end{array}$ & 42.0158 & 16.1540 & 0.0012 \\
\hline MGG_01305T0 & $\begin{array}{l}\text { MGG_01305 | Magnaporthe oryzae 70-15 } \\
\text { hypothetical protein (144 aa) }\end{array}$ & 119.4348 & 9.8019 & 0.0008 \\
\hline MGG_01708T0 & $\begin{array}{l}\text { MGG_01708 | Magnaporthe oryzae 70-15 } \\
\text { AN1-type zinc finger protein } 1 \text { (324 aa) }\end{array}$ & 9.9272 & 1.3623 & 0.0014 \\
\hline MGG_02109T0 & $\begin{array}{c}\text { MGG_02109 | Magnaporthe oryzae 70-15 } \\
\text { hypothetical protein (92 aa) }\end{array}$ & 15.4641 & 3.3675 & 0.0009 \\
\hline MGG_02537T0 & $\begin{array}{c}\text { MGG_02537 | Magnaporthe oryzae 70-15 } \\
\text { hypothetical protein (869 aa) }\end{array}$ & 25.4721 & 7.2297 & 0.0031 \\
\hline MGG_02944T0 & $\begin{array}{l}\text { MGG_02944 | Magnaporthe oryzae 70-15 } \\
\text { HAL protein kinase (851 aa) }\end{array}$ & 70.4324 & 1.2114 & 0.0037 \\
\hline MGG_03000T0 & $\begin{array}{l}\text { MGG_03000 | Magnaporthe oryzae 70-15 } \\
\text { hypothetical protein (592 aa) }\end{array}$ & 37.2745 & 2.2174 & 0.0057 \\
\hline MGG_03097T0 & $\begin{array}{c}\text { MGG_03097 | Magnaporthe oryzae 70-15 } \\
\text { oxidoreductase (445 aa) }\end{array}$ & 30.3224 & 1.7792 & 0.0068 \\
\hline MGG_03203T0 & $\begin{array}{c}\text { MGG_03203 | Magnaporthe oryzae 70-15 } \\
54 \text { S ribosomal protein L16 (252 aa) }\end{array}$ & 31.9276 & 1.8477 & 0.0063 \\
\hline MGG_03462T0 & $\begin{array}{l}\text { MGG_03462 | Magnaporthe oryzae 70-15 } \\
\text { hypothetical protein (585 aa) }\end{array}$ & 71.9726 & 6.3567 & 0.0080 \\
\hline MGG_03823T0 & $\begin{array}{c}\text { MGG_03823 | Magnaporthe oryzae 70-15 } \\
\text { NADH oxidase (419 aa) }\end{array}$ & 114.1477 & 6.4173 & 0.0058 \\
\hline MGG_03863T0 & $\begin{array}{c}\text { MGG_03863 | Magnaporthe oryzae 70-15 } \\
\text { hypothetical protein (187 aa) }\end{array}$ & 36.9956 & 3.2941 & 0.0061 \\
\hline MGG_04212T0 & $\begin{array}{c}\text { MGG_04212 | Magnaporthe oryzae 70-15 L- } \\
\text { ornithine 5-monooxygenase (L-ornithine } \\
\mathrm{N}(5) \text {-oxygenase) (564 aa) }\end{array}$ & 151.9231 & 3.0445 & 0.0081 \\
\hline MGG_04344T0 & $\begin{array}{c}\text { MGG_04344 | Magnaporthe oryzae 70-15 } \\
\text { hypothetical protein (563 aa) }\end{array}$ & 22.7061 & 5.1406 & 0.0091 \\
\hline MGG_04677T0 & $\begin{array}{c}\text { MGG_04677 | Magnaporthe oryzae 70-15 } \\
\text { hypothetical protein (646 aa) }\end{array}$ & 10.7469 & 10.0045 & 0.0129 \\
\hline
\end{tabular}




\begin{tabular}{|c|c|c|c|c|}
\hline MGG_04736T0 & $\begin{array}{l}\text { MGG_04736 | Magnaporthe oryzae 70-15 } \\
\text { hypothetical protein (304 aa) }\end{array}$ & 8.9216 & 1.8899 & 0.0129 \\
\hline MGG_04973T0 & $\begin{array}{l}\text { MGG_04973 | Magnaporthe oryzae 70-15 } \\
\text { carbonate dehydratase (273 aa) }\end{array}$ & 18.1819 & 2.1930 & 0.0107 \\
\hline MGG_05310T0 & $\begin{array}{l}\text { MGG_05310 | Magnaporthe oryzae 70-15 } \\
\text { sideroflexin-5 (341 aa) }\end{array}$ & 57.7183 & 2.9383 & 0.0128 \\
\hline MGG_05674T0 & $\begin{array}{l}\text { MGG_05674 | Magnaporthe oryzae 70-15 } \\
\text { hypothetical protein (411 aa) }\end{array}$ & 13.5068 & 0.9480 & 0.0126 \\
\hline MGG_05766T0 & $\begin{array}{l}\text { MGG_05766 | Magnaporthe oryzae 70-15 } \\
\text { hypothetical protein (288 aa) }\end{array}$ & 70.1020 & 1.6110 & 0.0139 \\
\hline MGG_05815T0 & $\begin{array}{l}\text { MGG_05815 | Magnaporthe oryzae 70-15 } \\
\text { pre-rRNA-processing protein ESF2 (331 aa) }\end{array}$ & 36.8337 & 4.6989 & 0.0190 \\
\hline MGG_05942T0 & $\begin{array}{l}\text { MGG_05942 | Magnaporthe oryzae } 70-15 \\
\text { flavin containing monooxygenase } 9 \text { ( } 533 \text { aa) }\end{array}$ & 8.1108 & 1.6052 & 0.0229 \\
\hline MGG_06151T0 & $\begin{array}{c}\text { MGG_06151 | Magnaporthe oryzae } 70-15 \\
\text { cytosolic Fe-S cluster assembly factor } \\
\text { NBP35 (344 aa) }\end{array}$ & 14.5954 & 3.1531 & 0.0173 \\
\hline MGG_06285T0 & $\begin{array}{l}\text { MGG_06285 | Magnaporthe oryzae 70-15 } \\
\text { hypothetical protein (978 aa) }\end{array}$ & 18.2848 & 1.7124 & 0.0214 \\
\hline MGG_06545T0 & $\begin{array}{c}\text { MGG_06545 | Magnaporthe oryzae 70-15 } \\
\text { hypothetical protein ( } 815 \text { aa) }\end{array}$ & 48.4118 & 3.0093 & 0.0204 \\
\hline MGG_06906T0 & $\begin{array}{l}\text { MGG_06906 | Magnaporthe oryzae 70-15 } \\
\text { hypothetical protein (568 aa) }\end{array}$ & 21.5556 & 3.8217 & 0.0188 \\
\hline MGG_07223T0 & $\begin{array}{c}\text { MGG_07223 | Magnaporthe oryzae 70-15 } \\
\text { altered inheritance-mitochondria protein } 31 \\
(214 \mathrm{aa})\end{array}$ & 56.7933 & 6.0552 & 0.0170 \\
\hline MGG_07369T0 & $\begin{array}{l}\text { MGG_07369 | Magnaporthe oryzae 70-15 } \\
\text { hypothetical protein (412 aa) }\end{array}$ & 170.7811 & 3.6872 & 0.0289 \\
\hline MGG_07394T0 & $\begin{array}{l}\text { MGG_07394 | Magnaporthe oryzae 70-15 } \\
\text { hypothetical protein (116 aa) }\end{array}$ & 33.1112 & 4.8728 & 0.0214 \\
\hline MGG_07697T0 & $\begin{array}{l}\text { MGG_07697 | Magnaporthe oryzae 70-15 } \\
\text { superoxide dismutase (214 aa) }\end{array}$ & 34.8546 & 3.3578 & 0.0195 \\
\hline MGG_07935T0 & $\begin{array}{c}\text { MGG_07935 | Magnaporthe oryzae 70-15 } \\
\text { galactonate dehydratase (384 aa) }\end{array}$ & 118.7296 & 4.5993 & 0.0206 \\
\hline MGG_08083T0 & $\begin{array}{l}\text { MGG_08083 | Magnaporthe oryzae 70-15 } \\
\text { hypothetical protein (546 aa) }\end{array}$ & 8.8913 & 3.5701 & 0.0231 \\
\hline MGG_08163T0 & $\begin{array}{l}\text { MGG_08163 | Magnaporthe oryzae 70-15 } \\
\text { 30S ribosomal protein S14p/S29e (57 aa) }\end{array}$ & 49.1428 & 2.9456 & 0.0284 \\
\hline MGG_08201T0 & $\begin{array}{l}\text { MGG_08201 | Magnaporthe oryzae 70-15 } \\
\text { hypothetical protein (137 aa) }\end{array}$ & 23.6339 & 4.8492 & 0.0249 \\
\hline MGG_08308T0 & $\begin{array}{c}\text { MGG_08308 | Magnaporthe oryzae 70-15 } \\
\text { hypothetical protein (282 aa) }\end{array}$ & 18.1492 & 2.5263 & 0.0331 \\
\hline MGG_08577T0 & $\begin{array}{l}\text { MGG_08577 | Magnaporthe oryzae 70-15 } \\
\text { hypothetical protein (432 aa) }\end{array}$ & 50.9072 & 4.1708 & 0.0255 \\
\hline MGG_08641T0 & $\begin{array}{l}\text { MGG_08641 | Magnaporthe oryzae 70-15 } \\
\text { pre-mRNA-splicing factor CWC2 (395 aa) }\end{array}$ & 46.4191 & 2.9320 & 0.0337 \\
\hline MGG_08688T0 & $\begin{array}{l}\text { MGG_08688 | Magnaporthe oryzae 70-15 } \\
\text { mitochondrial inner membrane protein (550 } \\
\text { aa) }\end{array}$ & 46.7370 & 0.8839 & 0.0335 \\
\hline MGG_08795T0 & $\begin{array}{l}\text { MGG_08795 | Magnaporthe oryzae 70-15 } \\
\text { hypothetical protein (595 aa) }\end{array}$ & 52.8734 & 0.9850 & 0.0383 \\
\hline MGG_09514T0 & $\begin{array}{c}\text { MGG_09514 | Magnaporthe oryzae 70-15 } \\
\text { methyltransferase OMS1 (487 aa) }\end{array}$ & 13.0378 & 6.0894 & 0.0387 \\
\hline MGG_10061T0 & $\begin{array}{c}\text { MGG_10061 | Magnaporthe oryzae 70-15 } \\
\text { catalase-1 (744 aa) }\end{array}$ & 153.3026 & 1.6070 & 0.0384 \\
\hline MGG_10111T0 & $\begin{array}{l}\text { MGG_10111 | Magnaporthe oryzae } 70-15 \\
\text { glucose and ribitol dehydrogenase ( } 347 \text { aa) }\end{array}$ & 41.9779 & 1.8394 & 0.0313 \\
\hline
\end{tabular}




\begin{tabular}{|c|c|c|c|c|}
\hline MGG_10274T0 & $\begin{array}{c}\text { MGG_10274 | Magnaporthe oryzae 70-15 } \\
\text { hypothetical protein (255 aa) }\end{array}$ & 219.8714 & 2.7055 & 0.0318 \\
\hline MGG_10441T0 & $\begin{array}{c}\text { MGG_10441 | Magnaporthe oryzae 70-15 } \\
\text { lipase } 2 \text { (338 aa) }\end{array}$ & 32.5816 & 1.7569 & 0.0339 \\
\hline MGG_11130T0 & $\begin{array}{c}\text { MGG_11130 | Magnaporthe oryzae 70-15 } \\
\text { hypothetical protein (713 aa) }\end{array}$ & 58.9006 & 1.3707 & 0.0355 \\
\hline MGG_12745T0 & $\begin{array}{c}\text { MGG_12745 | Magnaporthe oryzae 70-15 } \\
\text { hypothetical protein (507 aa) }\end{array}$ & 39.7800 & 1.4013 & 0.0377 \\
\hline MGG_13774T0 & $\begin{array}{c}\text { MGG_13774 | Magnaporthe oryzae 70-15 } \\
\text { hypothetical protein (340 aa) }\end{array}$ & 17.3119 & 1.9225 & 0.0475 \\
\hline MGG_14678T0 & $\begin{array}{c}\text { MGG_14678 | Magnaporthe oryzae 70-15 } \\
\text { hypothetical protein (409 aa) }\end{array}$ & 7.8653 & 1.0485 & 0.0367 \\
\hline MGG_15688T0 & $\begin{array}{c}\text { MGG_15688 | Magnaporthe oryzae 70-15 } \\
\text { hypothetical protein (692 aa) }\end{array}$ & 13.9507 & 5.0225 & 0.0425 \\
\hline MGG_16374T0 & $\begin{array}{c}\text { MGG_16374 | Magnaporthe oryzae 70-15 } \\
\text { hypothetical protein (351 aa) }\end{array}$ & 33.6181 & 0.9480 & 0.0409 \\
\hline MGG_17476T0 & $\begin{array}{c}\text { MGG_17476 | Magnaporthe oryzae 70-15 } \\
\text { hypothetical protein (253 aa) }\end{array}$ & 83.3382 & 4.0367 & 0.0484 \\
\hline MGG_17595T0 & $\begin{array}{c}\text { MGG_17595 | Magnaporthe oryzae 70-15 } \\
\text { hypothetical protein (510 aa) }\end{array}$ & 21.9518 & 4.1662 & 0.0437 \\
\hline MGG_17713T0 & $\begin{array}{c}\text { MGG_17713 | Magnaporthe oryzae 70-15 } \\
\text { hypothetical protein (637 aa) }\end{array}$ & 17.1908 & 0.8205 & 0.0452 \\
\hline MGG_17823T0 & $\begin{array}{c}\text { MGG_17823 | Magnaporthe oryzae 70-15 } \\
\text { cyanide hydratase (357 aa) }\end{array}$ & 109.7235 & 4.1150 & 0.0458 \\
\hline MGG_17829T0 & $\begin{array}{c}\text { MGG_17829 | Magnaporthe oryzae 70-15 } \\
\text { hypothetical protein (363 aa) }\end{array}$ & 59.7701 & 1.9857 & 0.0476 \\
\hline
\end{tabular}


Supplemental Table 3. Proteins unique to the Wild Type samples.

\begin{tabular}{|c|c|c|}
\hline Accession & Description & Total NSpC \\
\hline MGG_01080T0U & $\begin{array}{c}\text { MGG_01080 | Magnaporthe oryzae } 70-15 \text { hypothetical } \\
\text { protein (1465 aa) }\end{array}$ & 5.1437 \\
\hline MGG_07393T0U & $\begin{array}{c}\text { MGG_07393 | Magnaporthe oryzae 70-15 histone-lysine N- } \\
\text { methyltransferase SET9 (886 aa) }\end{array}$ & 5.1437 \\
\hline MGG_07953T0U & $\begin{array}{c}\text { MGG_07953 | Magnaporthe oryzae 70-15 bifunctional P- } \\
\text { 450:NADPH-P450 reductase (1096 aa) }\end{array}$ & 20.3819 \\
\hline MGG_07960T0U & $\begin{array}{c}\text { MGG_07960 | Magnaporthe oryzae 70-15 hypothetical } \\
\text { protein (401 aa) }\end{array}$ & 5.1482 \\
\hline MGG_08912T0U & $\begin{array}{c}\text { MGG_08912 | Magnaporthe oryzae } 70-15 \text { hypothetical } \\
\text { protein (446 aa) }\end{array}$ & 5.1437 \\
\hline MGG_09384T0U & $\begin{array}{c}\text { MGG_09384 | Magnaporthe oryzae 70-15 hypothetical } \\
\text { protein (514 aa) }\end{array}$ & 10.3053 \\
\hline MGG_09710T0U & $\begin{array}{c}\text { MGG_09710 | Magnaporthe oryzae 70-15 hypothetical } \\
\text { protein (294 aa) }\end{array}$ & 7.7290 \\
\hline MGG_10322T0U & $\begin{array}{c}\text { MGG_10322 | Magnaporthe oryzae } 70-15 \text { cortical patch } \\
\text { protein ( } 255 \text { aa) }\end{array}$ & 7.7156 \\
\hline MGG_12009T0U & $\begin{array}{c}\text { MGG_12009 | Magnaporthe oryzae } 70-15 \text { hypothetical } \\
\text { protein (858 aa) }\end{array}$ & 13.0625 \\
\hline MGG_12447T0U & $\begin{array}{l}\text { MGG_12447 | Magnaporthe oryzae 70-15 polyketide } \\
\text { synthase/peptide synthetase (4035 aa) }\end{array}$ & 5.0728 \\
\hline MGG_13065T0 & $\begin{array}{l}\text { MGG_13065 | Magnaporthe oryzae 70-15 SCF E3 ubiquitin } \\
\text { ligase complex F-box protein grrA (785 aa) }\end{array}$ & 16.6687 \\
\hline MGG_16007T0U & $\begin{array}{c}\text { MGG_16007 | Magnaporthe oryzae } 70-15 \text { hypothetical } \\
\text { protein (200 aa) }\end{array}$ & 5.1437 \\
\hline MGG_17263T0U & $\begin{array}{c}\text { MGG_17263 | Magnaporthe oryzae } 70-15 \text { hypothetical } \\
\text { protein (308 aa) }\end{array}$ & 6.0000 \\
\hline MGG_01996T1P & $\begin{array}{c}\text { MGG_01996 | Magnaporthe oryzae 70-15 hypothetical } \\
\text { protein (1015 aa) }\end{array}$ & 8.1667 \\
\hline MGG_06699T0P & $\begin{array}{c}\text { MGG_06699 | Magnaporthe oryzae 70-15 hypothetical } \\
\text { protein (480 aa) }\end{array}$ & 9.5569 \\
\hline MGG_06778TOP & $\begin{array}{c}\text { MGG_06778 | Magnaporthe oryzae 70-15 C6 zinc finger } \\
\text { domain-containing protein (725 aa) }\end{array}$ & 10.2254 \\
\hline MGG_07599T0P & $\begin{array}{c}\text { MGG_07599 | Magnaporthe oryzae 70-15 hypothetical } \\
\text { protein (141 aa) }\end{array}$ & 10.0951 \\
\hline MGG_14758T0P & $\begin{array}{c}\text { MGG_14758 | Magnaporthe oryzae 70-15 hypothetical } \\
\text { protein (190 aa) }\end{array}$ & 11.4847 \\
\hline MGG_00314T0UP & MGG_00314 | Magnaporthe oryzae 70-15 lipase 4 (599 aa) & 7.7290 \\
\hline MGG_00944T0UP & $\begin{array}{c}\text { MGG_00944 | Magnaporthe oryzae 70-15 hypothetical } \\
\text { protein (480 aa) }\end{array}$ & 11.5734 \\
\hline MGG_01638T0UP & $\begin{array}{c}\text { MGG_01638 | Magnaporthe oryzae 70-15 sodium/calcium } \\
\text { exchanger protein (1005 aa) }\end{array}$ & 7.5499 \\
\hline MGG_02309T0UP & $\begin{array}{l}\text { MGG_02309 | Magnaporthe oryzae 70-15 } \\
\text { carboxypeptidase S1 (635 aa) }\end{array}$ & 15.4579 \\
\hline MGG_03624T0UP & $\begin{array}{c}\text { MGG_03624 | Magnaporthe oryzae } 70-15 \text { hypothetical } \\
\text { protein ( } 230 \text { aa) }\end{array}$ & 10.0000 \\
\hline MGG_04329T0UP & $\begin{array}{c}\text { MGG_04329 | Magnaporthe oryzae 70-15 hypothetical } \\
\text { protein (516 aa) }\end{array}$ & 5.3298 \\
\hline MGG_07586T0UP & $\begin{array}{c}\text { MGG_07586 | Magnaporthe oryzae } 70-15 \text { trichothecene C- } \\
15 \text { hydroxylase }(167 \mathrm{aa})\end{array}$ & 6.1250 \\
\hline MGG_07817T0UP & $\begin{array}{c}\text { MGG_07817 | Magnaporthe oryzae 70-15 hypothetical } \\
\text { protein (602 aa) }\end{array}$ & 5.0728 \\
\hline MGG_07972T0UP & $\begin{array}{c}\text { MGG_07972 | Magnaporthe oryzae 70-15 hypothetical } \\
\text { protein (292 aa) }\end{array}$ & 5.9855 \\
\hline
\end{tabular}




\begin{tabular}{|c|c|c|}
\hline MGG_08348T0UP & $\begin{array}{c}\text { MGG_08348 | Magnaporthe oryzae } 70-15 \text { hypothetical } \\
\text { protein (82 aa) }\end{array}$ & 5.1437 \\
\hline MGG_09236T0UP & $\begin{array}{c}\text { MGG_09236 | Magnaporthe oryzae 70-15 hypothetical } \\
\text { protein (857 aa) }\end{array}$ & 11.9426 \\
\hline MGG_12530T0UP & $\begin{array}{l}\text { MGG_12530 | Magnaporthe oryzae 70-15 histidine kinase } \\
\text { G7 (1272 aa) }\end{array}$ & 6.4891 \\
\hline MGG_13542T0UP & $\begin{array}{c}\text { MGG_13542 | Magnaporthe oryzae 70-15 DEAD_2 domain- } \\
\text { containing protein (922 aa) }\end{array}$ & 5.1437 \\
\hline MGG_00052T0 & $\begin{array}{c}\text { MGG_00052 | Magnaporthe oryzae } 70-15 \text { hypothetical } \\
\text { protein (225 aa) }\end{array}$ & 7.1753 \\
\hline MGG_00521T0 & $\begin{array}{c}\text { MGG_00521 | Magnaporthe oryzae 70-15 hypothetical } \\
\text { protein (874 aa) }\end{array}$ & 6.2960 \\
\hline MGG_00532T0 & $\begin{array}{c}\text { MGG_00532 | Magnaporthe oryzae 70-15 hypothetical } \\
\text { protein (530 aa) }\end{array}$ & 14.8194 \\
\hline MGG_01814T0 & $\begin{array}{c}\text { MGG_01814 | Magnaporthe oryzae } 70-15 \text { hypothetical } \\
\text { protein (460 aa) }\end{array}$ & 5.0562 \\
\hline MGG_01941T0 & $\begin{array}{c}\text { MGG_01941 | Magnaporthe oryzae 70-15 FAD binding } \\
\text { domain-containing protein (521 aa) }\end{array}$ & 11.0618 \\
\hline MGG_03070T0 & $\begin{array}{l}\text { MGG_03070 | Magnaporthe oryzae 70-15 epoxide } \\
\text { hydrolase domain-containing protein ( } 411 \text { aa) }\end{array}$ & 87.2954 \\
\hline MGG_03347T0 & $\begin{array}{c}\text { MGG_03347 | Magnaporthe oryzae 70-15 hypothetical } \\
\text { protein (275 aa) }\end{array}$ & 9.7565 \\
\hline MGG_04346T0 & $\begin{array}{c}\text { MGG_04346 | Magnaporthe oryzae 70-15 sterol 24-C- } \\
\text { methyltransferase (391 aa) }\end{array}$ & 27.4567 \\
\hline MGG_05005T0 & $\begin{array}{c}\text { MGG_05005 | Magnaporthe oryzae 70-15 LMBR1 domain- } \\
\text { containing protein (728 aa) }\end{array}$ & 5.5433 \\
\hline MGG_05022T0 & $\begin{array}{c}\text { MGG_05022 | Magnaporthe oryzae 70-15 hypothetical } \\
\text { protein (322 aa) }\end{array}$ & 11.0813 \\
\hline MGG_05033T0 & $\begin{array}{c}\text { MGG_05033 | Magnaporthe oryzae 70-15 hypothetical } \\
\text { protein (743 aa) }\end{array}$ & 6.0309 \\
\hline MGG_05139T0 & $\begin{array}{c}\text { MGG_05139 | Magnaporthe oryzae } 70-15 \text { hypothetical } \\
\text { protein (477 aa) }\end{array}$ & 6.9786 \\
\hline MGG_05272T0 & $\begin{array}{c}\text { MGG_05272 | Magnaporthe oryzae 70-15 hypothetical } \\
\text { protein (785 aa) }\end{array}$ & 7.4783 \\
\hline MGG_05756T0 & $\begin{array}{c}\text { MGG_05756 | Magnaporthe oryzae } 70-15 \text { hypothetical } \\
\text { protein ( } 250 \mathrm{aa})\end{array}$ & 5.9784 \\
\hline MGG_05968T0 & $\begin{array}{c}\text { MGG_05968 | Magnaporthe oryzae 70-15 } \\
\text { endoribonuclease L-PSP (137 aa) }\end{array}$ & 8.0859 \\
\hline MGG_06893T0 & $\begin{array}{c}\text { MGG_06893 | Magnaporthe oryzae } 70-15 \text { hypothetical } \\
\text { protein (548 aa) }\end{array}$ & 5.0816 \\
\hline MGG_10156T0 & $\begin{array}{c}\text { MGG_10156 | Magnaporthe oryzae 70-15 hypothetical } \\
\text { protein (185 aa) }\end{array}$ & 14.1536 \\
\hline MGG_10252T0 & $\begin{array}{c}\text { MGG_10252 | Magnaporthe oryzae 70-15 hypothetical } \\
\text { protein (487 aa) }\end{array}$ & 328.0972 \\
\hline MGG_10533T0 & $\begin{array}{c}\text { MGG_10533 | Magnaporthe oryzae 70-15 agmatinase } 1 \\
\text { (424 aa) }\end{array}$ & 30.9978 \\
\hline MGG_10596T1 & $\begin{array}{c}\text { MGG_10596 | Magnaporthe oryzae 70-15 CMGC/SRPK } \\
\text { protein kinase (534 aa) }\end{array}$ & 15.6928 \\
\hline MGG_11431T0 & $\begin{array}{c}\text { MGG_11431 | Magnaporthe oryzae 70-15 cytochrome c } \\
\text { oxidase assembly protein COX11 (261 aa) }\end{array}$ & 5.3099 \\
\hline MGG_12124T0 & $\begin{array}{c}\text { MGG_12124 | Magnaporthe oryzae 70-15 hypothetical } \\
\text { protein (54 aa) }\end{array}$ & 10.5533 \\
\hline MGG_13185T0 & $\begin{array}{c}\text { MGG_13185 | Magnaporthe oryzae 70-15 inositol-3- } \\
\text { phosphate synthase (553 aa) }\end{array}$ & 14.1875 \\
\hline MGG_13455T0 & $\begin{array}{c}\text { MGG_13455 | Magnaporthe oryzae } 70-15 \text { hypothetical } \\
\text { protein (469 aa) }\end{array}$ & 5.0136 \\
\hline MGG_13493T0 & $\begin{array}{l}\text { MGG_13493 | Magnaporthe oryzae 70-15 F-box protein } \\
\text { (561 aa) }\end{array}$ & 5.5433 \\
\hline
\end{tabular}




\begin{tabular}{|c|c|c|}
\hline MGG_16418T0 & $\begin{array}{c}\text { MGG_16418 | Magnaporthe oryzae } 70-15 \text { hypothetical } \\
\text { protein }(220 \text { aa) }\end{array}$ & 5.6696 \\
\hline MGG_17677T0 & $\begin{array}{c}\text { MGG_17677 | Magnaporthe oryzae } 70-15 \text { hypothetical } \\
\text { protein (618 aa) }\end{array}$ & 5.0527 \\
\hline MGG_17979T0 & $\begin{array}{c}\text { MGG_17979 | Magnaporthe oryzae } 70-15 \text { hypothetical } \\
\text { protein (145 aa) }\end{array}$ & 10.1042 \\
\hline
\end{tabular}


Supplemental Table 4. Proteins unique to the E3 Ligase knockout samples.

\begin{tabular}{|c|c|c|}
\hline Accession & Description & Total NSpC \\
\hline MGG_02114T0U & $\begin{array}{l}\text { MGG_02114 | Magnaporthe oryzae } 70-15 \text { hypothetical protein } \\
\text { (813 aa) }\end{array}$ & 6.2703 \\
\hline MGG_02377T0U & $\begin{array}{l}\text { MGG_02377 | Magnaporthe oryzae 70-15 hypothetical protein } \\
\text { (884 aa) }\end{array}$ & 7.9145 \\
\hline MGG_06430T0U & $\begin{array}{l}\text { MGG_06430 | Magnaporthe oryzae } 70-15 \text { hypothetical protein } \\
(565 \text { aa })\end{array}$ & 9.0409 \\
\hline MGG_07598T0U & $\begin{array}{l}\text { MGG_07598 | Magnaporthe oryzae 70-15 hypothetical protein } \\
\qquad(200 \text { aa) }\end{array}$ & 5.2048 \\
\hline MGG_07905T0U & $\begin{array}{l}\text { MGG_07905 | Magnaporthe oryzae 70-15 hypothetical protein } \\
(1974 \text { aa })\end{array}$ & 5.4579 \\
\hline MGG_08467T0U & $\begin{array}{c}\text { MGG_08467 | Magnaporthe oryzae 70-15 hypothetical protein } \\
\text { (412 aa) }\end{array}$ & 5.2048 \\
\hline MGG_08697T0U & $\begin{array}{c}\text { MGG_08697 | Magnaporthe oryzae 70-15 hypothetical protein } \\
(1249 \text { aa) }\end{array}$ & 6.5060 \\
\hline MGG_13692T0U & $\begin{array}{l}\text { MGG_13692 | Magnaporthe oryzae 70-15 hypothetical protein } \\
\text { (87 aa) }\end{array}$ & 13.1909 \\
\hline MGG_17625T0U & $\begin{array}{l}\text { MGG_17625 | Magnaporthe oryzae } 70-15 \text { hypothetical protein } \\
\text { (814 aa) }\end{array}$ & 5.7229 \\
\hline MGG_05047T0P & $\begin{array}{l}\text { MGG_05047 | Magnaporthe oryzae 70-15 hypothetical protein } \\
\text { (883 aa) }\end{array}$ & 14.5125 \\
\hline MGG_08007T0P & $\begin{array}{l}\text { MGG_08007 | Magnaporthe oryzae 70-15 hypothetical protein } \\
(254 \text { aa) }\end{array}$ & 7.2163 \\
\hline MGG_08811T0P & $\begin{array}{l}\text { MGG_08811 | Magnaporthe oryzae } 70-15 \text { hypothetical protein } \\
(320 \text { aa })\end{array}$ & 5.5448 \\
\hline MGG_08946T0P & $\begin{array}{l}\text { MGG_08946 | Magnaporthe oryzae 70-15 hypothetical protein } \\
(237 \text { aa) }\end{array}$ & 11.7286 \\
\hline MGG_08985T0P & $\begin{array}{l}\text { MGG_08985 | Magnaporthe oryzae 70-15 beta-xylosidase } \\
\text { (848 aa) }\end{array}$ & 5.2763 \\
\hline MGG_11606T0P & $\begin{array}{l}\text { MGG_11606 | Magnaporthe oryzae 70-15 hypothetical protein } \\
\text { (343 aa) }\end{array}$ & 18.2571 \\
\hline MGG_14575T0P & $\begin{array}{l}\text { MGG_14575 | Magnaporthe oryzae 70-15 hypothetical protein } \\
\text { (514 aa) }\end{array}$ & 5.7277 \\
\hline MGG_00072T0UP & $\begin{array}{c}\text { MGG_00072 | Magnaporthe oryzae 70-15 isoamyl alcohol } \\
\text { oxidase }(600 \text { aa) }\end{array}$ & 5.2286 \\
\hline MGG_02342T0UP & $\begin{array}{l}\text { MGG_02342 | Magnaporthe oryzae 70-15 hypothetical protein } \\
\text { (853 aa) }\end{array}$ & 11.7644 \\
\hline MGG_02408T0UP & $\begin{array}{l}\text { MGG_02408 | Magnaporthe oryzae 70-15 hypothetical protein } \\
\text { (929 aa) }\end{array}$ & 8.7239 \\
\hline MGG_02508T0UP & $\begin{array}{l}\text { MGG_02508 | Magnaporthe oryzae 70-15 hypothetical protein } \\
(269 \text { aa) }\end{array}$ & 5.9899 \\
\hline MGG_02988T0UP & $\begin{array}{c}\text { MGG_02988 | Magnaporthe oryzae 70-15 hypothetical protein } \\
\text { (384 aa) }\end{array}$ & 11.8718 \\
\hline MGG_04685T0UP & $\begin{array}{l}\text { MGG_04685 | Magnaporthe oryzae 70-15 hypothetical protein } \\
(1459 \text { aa) }\end{array}$ & 9.2336 \\
\hline MGG_04929T0UP & $\begin{array}{l}\text { MGG_04929 | Magnaporthe oryzae 70-15 hypothetical protein } \\
(750 \text { aa) }\end{array}$ & 8.9518 \\
\hline MGG_05798T0UP & $\begin{array}{l}\text { MGG_05798 | Magnaporthe oryzae 70-15 hypothetical protein } \\
(217 \text { aa) }\end{array}$ & 5.2048 \\
\hline MGG_05938T0UP & $\begin{array}{c}\text { MGG_05938 | Magnaporthe oryzae 70-15 2,2-dialkylglycine } \\
\text { decarboxylase (452 aa) }\end{array}$ & 5.2286 \\
\hline MGG_07476T0UP & $\begin{array}{l}\text { MGG_07476 | Magnaporthe oryzae 70-15 hypothetical protein } \\
\text { (872 aa) }\end{array}$ & 5.1973 \\
\hline
\end{tabular}




\begin{tabular}{|c|c|c|}
\hline MGG_07975T0UP & $\begin{array}{l}\text { MGG_07975 | Magnaporthe oryzae 70-15 hypothetical protein } \\
\text { (193 aa) }\end{array}$ & 5.2763 \\
\hline MGG_08174T0UP & $\begin{array}{c}\text { MGG_08174 | Magnaporthe oryzae 70-15 mitogen-activated } \\
\text { protein kinase organizer } 1 \text { (358 aa) }\end{array}$ & 5.2406 \\
\hline MGG_08211T0UP & $\begin{array}{l}\text { MGG_08211 | Magnaporthe oryzae 70-15 hypothetical protein } \\
\text { (572 aa) }\end{array}$ & 7.8072 \\
\hline MGG_08919T0UP & $\begin{array}{c}\text { MGG_08919 | Magnaporthe oryzae 70-15 UDP-glucose,sterol } \\
\text { transferase (1324 aa) }\end{array}$ & 11.0897 \\
\hline MGG_09185T0UP & $\begin{array}{l}\text { MGG_09185 | Magnaporthe oryzae 70-15 hypothetical protein } \\
(1228 \text { aa) }\end{array}$ & 7.1879 \\
\hline MGG_09262T0UP & $\begin{array}{l}\text { MGG_09262 | Magnaporthe oryzae 70-15 autophagy protein } 5 \\
(315 \text { aa) }\end{array}$ & 7.2644 \\
\hline MGG_09537T0UP & $\begin{array}{c}\text { MGG_09537 | Magnaporthe oryzae 70-15 MSF1 domain- } \\
\text { containing protein (233 aa) }\end{array}$ & 21.5637 \\
\hline MGG_10001T0UP & $\begin{array}{l}\text { MGG_10001 | Magnaporthe oryzae 70-15 hypothetical protein } \\
(265 \text { aa) }\end{array}$ & 5.9899 \\
\hline MGG_10086T0UP & $\begin{array}{l}\text { MGG_10086 | Magnaporthe oryzae 70-15 hypothetical protein } \\
\text { (129 aa) }\end{array}$ & 5.2763 \\
\hline MGG_11230T0UP & $\begin{array}{l}\text { MGG_11230 | Magnaporthe oryzae 70-15 hypothetical protein } \\
\text { (601 aa) }\end{array}$ & 5.9907 \\
\hline MGG_12714T0UP & $\begin{array}{c}\text { MGG_12714 | Magnaporthe oryzae 70-15 hypothetical protein } \\
\text { (310 aa) }\end{array}$ & 6.2681 \\
\hline MGG_12858T0UP & $\begin{array}{l}\text { MGG_12858 | Magnaporthe oryzae 70-15 hypothetical protein } \\
(254 \text { aa) }\end{array}$ & 11.6665 \\
\hline MGG_14578T0UP & $\begin{array}{l}\text { MGG_14578 | Magnaporthe oryzae 70-15 hypothetical protein } \\
(285 \text { aa) }\end{array}$ & 8.9161 \\
\hline MGG_00199T0 & $\begin{array}{l}\text { MGG_00199 | Magnaporthe oryzae 70-15 hypothetical protein } \\
(1296 \text { aa) }\end{array}$ & 8.6501 \\
\hline MGG_00569T0 & $\begin{array}{l}\text { MGG_00569 | Magnaporthe oryzae 70-15 hypothetical protein } \\
\text { (772 aa) }\end{array}$ & 9.9302 \\
\hline MGG_02648T0 & $\begin{array}{c}\text { MGG_02648 | Magnaporthe oryzae 70-15 interferon-induced } \\
\text { GTP-binding protein Mx (734 aa) }\end{array}$ & 57.3946 \\
\hline MGG_03098T0 & $\begin{array}{c}\text { MGG_03098 | Magnaporthe oryzae 70-15 thiazole } \\
\text { biosynthetic enzyme (328 aa) }\end{array}$ & 7.1729 \\
\hline MGG_03162T0 & $\begin{array}{l}\text { MGG_03162 | Magnaporthe oryzae 70-15 hypothetical protein } \\
(1010 \text { aa) }\end{array}$ & 16.4886 \\
\hline MGG_03542T0 & $\begin{array}{c}\text { MGG_03542 | Magnaporthe oryzae 70-15 metallopeptidase } \\
\text { (807 aa) }\end{array}$ & 40.5928 \\
\hline MGG_03567T0 & $\begin{array}{l}\text { MGG_03567 | Magnaporthe oryzae 70-15 hypothetical protein } \\
\text { (317 aa) }\end{array}$ & 6.5238 \\
\hline MGG_04133T0 & $\begin{array}{c}\text { MGG_04133 | Magnaporthe oryzae 70-15 histone } \\
\text { acetyltransferase esa-1 (535 aa) }\end{array}$ & 5.1075 \\
\hline MGG_04196T0 & $\begin{array}{l}\text { MGG_04196 | Magnaporthe oryzae 70-15 hypothetical protein } \\
\qquad(1132 \text { aa) }\end{array}$ & 25.8386 \\
\hline MGG_04559T0 & $\begin{array}{c}\text { MGG_04559 | Magnaporthe oryzae } 70-15 \text { exocyst complex } \\
\text { component protein (852 aa) }\end{array}$ & 8.0683 \\
\hline MGG_04803T0 & $\begin{array}{l}\text { MGG_04803 | Magnaporthe oryzae } 70-15 \text { transmembrane } \\
\text { and coiled-coil domain-containing protein } 4(1375 \text { aa) }\end{array}$ & 12.4507 \\
\hline MGG_05281T1 & $\begin{array}{l}\text { MGG_05281 | Magnaporthe oryzae 70-15 superoxide } \\
\text { dismutase copper chaperone Lys7 ( } 267 \text { aa) }\end{array}$ & 9.1779 \\
\hline MGG_05785T0 & MGG_05785 | Magnaporthe oryzae 70-15 levanase (660 aa) & 6.3435 \\
\hline MGG_06010T0 & $\begin{array}{l}\text { MGG_06010 | Magnaporthe oryzae 70-15 hypothetical protein } \\
(125 \text { aa) }\end{array}$ & 6.1671 \\
\hline MGG_06324T0 & $\begin{array}{c}\text { MGG_06324 | Magnaporthe oryzae 70-15 dTDP-D-glucose } \\
\text { 4,6-dehydratase (425 aa) }\end{array}$ & 5.5861 \\
\hline MGG_06482T1 & $\begin{array}{c}\text { MGG_06482 | Magnaporthe oryzae 70-15 STE/STE7 protein } \\
\text { kinase (516 aa) }\end{array}$ & 12.4312 \\
\hline
\end{tabular}




\begin{tabular}{|c|c|c|}
\hline MGG_07408T0 & $\begin{array}{c}\text { MGG_07408 | Magnaporthe oryzae 70-15 NACHT and TPR } \\
\text { domain-containing protein (2126 aa) }\end{array}$ & 10.7315 \\
\hline MGG_08139T0 & $\begin{array}{c}\text { MGG_08139 | Magnaporthe oryzae 70-15 methionine } \\
\text { aminopeptidase } 1 \text { (396 aa) }\end{array}$ & 67.5144 \\
\hline MGG_08341T0 & $\begin{array}{c}\text { MGG_08341 | Magnaporthe oryzae } 70-15 \text { hypothetical protein } \\
\text { (250 aa) }\end{array}$ & 6.7707 \\
\hline MGG_08699T0 & $\begin{array}{l}\text { MGG_08699 | Magnaporthe oryzae 70-15 hypothetical protein } \\
\text { (219 aa) }\end{array}$ & 5.8875 \\
\hline MGG_08949T0 & $\begin{array}{l}\text { MGG_08949 | Magnaporthe oryzae 70-15 hypothetical protein } \\
\text { (411 aa) }\end{array}$ & 7.2644 \\
\hline MGG_09777T0 & $\begin{array}{c}\text { MGG_09777 | Magnaporthe oryzae 70-15 trichothecene 3-O- } \\
\text { acetyltransferase (474 aa) }\end{array}$ & 5.7312 \\
\hline MGG_10359T0 & $\begin{array}{l}\text { MGG_10359 | Magnaporthe oryzae 70-15 hypothetical protein } \\
(416 \text { aa) }\end{array}$ & 5.6160 \\
\hline MGG_10716T0 & $\begin{array}{l}\text { MGG_10716 | Magnaporthe oryzae 70-15 hypothetical protein } \\
(180 \text { aa })\end{array}$ & 9.5669 \\
\hline MGG_11475T0 & $\begin{array}{l}\text { MGG_11475 | Magnaporthe oryzae 70-15 hypothetical protein } \\
\qquad(1029 \text { aa) }\end{array}$ & 6.2467 \\
\hline MGG_11761T0 & $\begin{array}{l}\text { MGG_11761 | Magnaporthe oryzae 70-15 hypothetical protein } \\
\text { (619 aa) }\end{array}$ & 7.0266 \\
\hline MGG_11907T0 & $\begin{array}{c}\text { MGG_11907 | Magnaporthe oryzae 70-15 hypothetical protein } \\
\text { (461 aa) }\end{array}$ & 6.0028 \\
\hline MGG_13796T0 & $\begin{array}{c}\text { MGG_13796 | Magnaporthe oryzae } 70-15 \text { stress responsive } \\
\text { A/B barrel domain-containing protein }(111 \mathrm{aa})\end{array}$ & 8.0652 \\
\hline MGG_14388T0 & $\begin{array}{l}\text { MGG_14388 | Magnaporthe oryzae } 70-15 \text { hypothetical protein } \\
\text { (202 aa) }\end{array}$ & 19.4916 \\
\hline MGG_15612T0 & $\begin{array}{l}\text { MGG_15612 | Magnaporthe oryzae 70-15 hypothetical protein } \\
(1340 \mathrm{aa})\end{array}$ & 18.6143 \\
\hline MGG_15825T0 & $\begin{array}{l}\text { MGG_15825 | Magnaporthe oryzae 70-15 hypothetical protein } \\
\text { (593 aa) }\end{array}$ & 6.6759 \\
\hline MGG_17682T0 & $\begin{array}{l}\text { MGG_17682 | Magnaporthe oryzae } 70-15 \text { hypothetical protein } \\
\qquad(150 \text { aa })\end{array}$ & 6.4147 \\
\hline
\end{tabular}

\footnotetext{
$\cup$ Ubiquitinated

P Phosphorylated

UP Ubiquitinated and Phosphorylated
} 
Supplemental Table 5. Post-translational modification sites of proteins listed in Supplemental Tables 1-4.

\begin{tabular}{|c|c|c|}
\hline Accession & Peptides & Modification position \\
\hline MGG_01364T0 & SRPVDPSLPQGDLR & 2xGG [S1; S7] \\
\hline MGG_02398T0 & AVFGGAVK & 1XGG [K8] \\
\hline MGG_03223T0 & EDVVAIETILR & 1xGG [T8] \\
\hline MGG_05937T0 & TPTMTSR & 2xGG [T1; T3] \\
\hline MGG_05981T0 & MTMTEVK & 2xOxidation [M1; M3]; 1xGG [T4] \\
\hline MGG_06026T0 & FTSVPVER & 1xGG [S3] \\
\hline MGG_08290T0 & TATITR & 1xGG [T1] \\
\hline MGG_09215T0 & VELPTTNAQTVR & $1 \times G G[T]$ \\
\hline MGG_12004T0 & QVLSIDVVGGK & 1xGG [S4] \\
\hline \multirow{2}{*}{ MGG_02701T0 } & SHSDAATRPIIVTTTK & 1XPhospho [S3] \\
\hline & RLSGSLEVPNSPLR & 1xPhospho [S3] \\
\hline MGG_06404T0 & EACCALLLGNSTTSLAALTLSETAK & $\begin{array}{c}\text { 2xNethylmaleimide [C3; C4]; } \\
\text { 1xPhospho [T23] }\end{array}$ \\
\hline MGG_07222T0 & AGNGGVIVDGASPILKDILK & 1xPhospho [S12] \\
\hline MGG_08267T0 & $\begin{array}{c}\text { TGTPIWAIIFDLEGGAINDVPMNATAYA } \\
\text { HR }\end{array}$ & 1xOxidation [M22]; 1xPhospho [Y/T] \\
\hline MGG_09394T0 & TSSTLSLTAR & 1xPhospho [T/S] \\
\hline MGG_09838T0 & NAASETTSLLR & 1xPhospho [S/T] \\
\hline MGG_11100T0 & GSSVSGGVSGHLAK & 1xPhospho [S] \\
\hline MGG_11899T0 & SASPNPYTASER & 1xPhospho [S3] \\
\hline MGG_03192T0 & $\begin{array}{l}\text { SSTPQPATNGNAANGSAAVSFASTAS } \\
\text { NNASK }\end{array}$ & 1xPhospho [T/S]; 1xGG [S20] \\
\hline \multirow{2}{*}{ MGG_03286T0 } & SSLGSVNADGVSDRPDSSK & 2xPhospho [S2; S] \\
\hline & AMQMSSPAPSVFSTPR & 2xGG [S5; S6] \\
\hline MGG_02055T0 & QTVNASQIVRSHGISR & 2xGG [T2; S15] \\
\hline MGG_08005T0 & $\begin{array}{l}\text { SETATTIGAENGASSSAASLPAEVSG } \\
\text { GSK }\end{array}$ & 3xGG [T3; T5; S28] \\
\hline \multirow{2}{*}{ MGG_12999T0 } & VEDLVAPK & 1XGG [K8] \\
\hline & QTGELAAALAGR & 1XGG [T2] \\
\hline MGG_05257T0 & SATPSHATSMPMPIPR & 1xPhospho [S/T] \\
\hline MGG_01080T0 & ENADPASPTTPARKVTLAEYQAAK & 1xGG $[K / T]$ \\
\hline MGG_07393T0 & $\begin{array}{c}\text { AEVSETSTITVVNSVEGDSTSVIAGEV } \\
\text { AR }\end{array}$ & 1xGG [T/S]; 1xLeuArgGlyGly [S/T] \\
\hline MGG_07953T0 & LVTSGVSTLR & 2xGG [S4; S7] \\
\hline MGG_07960T0 & IQLIDPGSDTLDEAPTVIR & 1XGG [T/S] \\
\hline MGG_08912T0 & IELVPTSGAR & 1XGG [S/T] \\
\hline MGG_09384T0 & SLTAATAQTAAAVR & 2xGG [S/T]; 1xLeuArgGlyGly [T/S] \\
\hline MGG_09710T0 & $\begin{array}{c}\text { AAQQCSASQTSPSASMPTSTPTMVG } \\
\text { MPK }\end{array}$ & $\begin{array}{l}\text { 2xGG [T20; T]; 1xNethylmaleimide [C5]; } \\
\text { 1xOxidation [M] }\end{array}$ \\
\hline MGG_10322T0 & $\begin{array}{c}\text { LGAAMAGLVAGTALFFNTLAVCLMTA } \\
\text { TFVK }\end{array}$ & $\begin{array}{c}\text { 1xGG [K/T]; 2xOxidation [M5; M24]; } \\
\text { 1xNethylmaleimide [C22] }\end{array}$ \\
\hline MGG_12009T0 & $\begin{array}{c}\text { GMSIASLEAPTTPTSIGESALPAKHQS } \\
\text { VMSK }\end{array}$ & $\begin{array}{c}\text { 2xGG [S15; S19]; 1xLeuArgGlyGly } \\
\text { [K/S] }\end{array}$ \\
\hline MGG_12447T0 & APSAAAVFYTSGSTGVPK & 1XGG [T/S] \\
\hline MGG_13065T0 & AITDTAVYAISK & 1XGG [T5] \\
\hline MGG_16007T0 & $\begin{array}{c}\text { WLLNPATAAQTGTGMATATAETAFLA } \\
\text { TGY }\end{array}$ & $2 \times G G[T]$ \\
\hline MGG_17263T0 & $\begin{array}{c}\text { TCSTTVFLPPIQPDALMMPTPSLGNW } \\
\text { PVHIGQSSPRAR }\end{array}$ & $\begin{array}{c}\text { 1xGG [T/S]; 1xNethylmaleimide [C2]; } \\
\text { 2xOxidation [M17; M18] }\end{array}$ \\
\hline MGG_01996T1 & YRLTAGYYGMGQQLR & 1XPhospho [Y/T] \\
\hline MGG 06699T0 & SSPTADYPGSMR & 1xPhospho [S] \\
\hline MGG 06778T0 & SGTGGPLPVDSGSPNLAGR & 1xPhospho [S/T] \\
\hline MGG_07599T0 & QATAQHESLPNALTPGK & 1xPhospho [T14] \\
\hline
\end{tabular}




\begin{tabular}{|c|c|c|}
\hline MGG_14758T0 & DSWTSLASEAPAAVR & 1xPhospho [S/T] \\
\hline MGG_00314T0 & ASILSAFSAVFLTVAGSQVIR & 2xGG [S/T]; 1xPhospho [S/T] \\
\hline MGG_00944T0 & $\begin{array}{c}\text { TTTNNNGGQMVPPPAPTSGQTDSHS } \\
\text { MVYQHIQETASKR }\end{array}$ & $\begin{array}{c}\text { 1xGG [S/K]; 1xOxidation [M10]; } \\
\text { 1xPhospho [T] }\end{array}$ \\
\hline \multirow{2}{*}{ MGG_01638T0 } & $\begin{array}{c}\text { LGYPVMALAACFGGPMLNILLGIGIGG } \\
\text { AWMTTK }\end{array}$ & $\begin{array}{c}\text { 1xGG [K/T]; 2xPhospho [Y3; T32]; } \\
\text { 1xNethylmaleimide [C11] }\end{array}$ \\
\hline & SHGTLPSVWTFPGPSSAPR & 1xPhospho [S]; 1xLeuArgGlyGly [S1] \\
\hline MGG_02309T0 & TLAPGSPIPPTNTTFR & $\begin{array}{l}\text { 1xGG [T]; 1xPhospho [T]; } \\
\text { 1xLeuArgGlyGly [T] }\end{array}$ \\
\hline MGG_03624T0 & $\begin{array}{c}\text { GVSAPSRPRCGSSPSRPGPFATFAIC } \\
\text { MMTTGTITLLSACK }\end{array}$ & $\begin{array}{c}\text { 1xGG [S/T]; 1xPhospho [S/T]; } \\
\text { 3xNethylmaleimide [C10; C26; C39] }\end{array}$ \\
\hline MGG_04329T0 & $\begin{array}{c}\text { GSMLGPALGTCNGISALGPVIGGAMA } \\
\text { LGTSGSK }\end{array}$ & $\begin{array}{c}\text { 1xGG [S2]; 1xPhospho [T10]; } \\
\text { 1xNethylmaleimide [C11]; 1xOxidation } \\
\text { [M3] }\end{array}$ \\
\hline MGG_07586T0 & IAAPSATTIVGHYIR & 1xPhospho [T/S]; 1xGG [S/T] \\
\hline MGG_07817T0 & HPRSTLPTRPTR & 1xGG [T/S]; 1xPhospho [T] \\
\hline MGG_07972T0 & IETSTAPPSAGSVK & 2xGG [S9; S]; 1xPhospho [T/S] \\
\hline MGG_08348T0 & ISVAAISMALLSLASAAPATQAAPIEAR & 1xGG [S]; 1xPhospho [T20] \\
\hline MGG_09236T0 & TAASRPESSLGVSELPR & 1xGG [S/T]; 1xPhospho [T/S] \\
\hline \multirow{2}{*}{ MGG_12530T0 } & EGSVSALGPADAPTK & 1xGG [S3] \\
\hline & GSADPALTTFAELAVLR & 1xPhospho [T/S] \\
\hline MGG_13542T0 & $\begin{array}{c}\text { MEYIDSSTVAGLLDKQNGTTAGDVSA } \\
\text { RESTPSATVTKPPSTITR }\end{array}$ & 2xGG [S7; S25]; 1xPhospho [S/T] \\
\hline MGG_02114T0 & TYIGIAIR & 1xGG [T1] \\
\hline MGG_02377T0 & $\begin{array}{c}\text { VEHAALPPRAGLSPASAAAGPAGEGS } \\
\text { VTGSPSVGSAK }\end{array}$ & $1 \times G G[S / T / K]$ \\
\hline MGG_06430T0 & MSETSALLPSTR & 1xGG [S/T]; 1xLeuArgGlyGI \\
\hline MGG_07598T0 & STGSITTSAVPIATAGAGR & 1xGG [S/T] \\
\hline MGG_07905T0 & STPEIIGVFIR & $1 \times G G[T / S]$ \\
\hline MGG_08467T0 & $\begin{array}{c}\text { GGKAPGAPAQSTTNTNKPAVGSTGTT } \\
\text { SPAPNLACAPGANK }\end{array}$ & 2xGG [T/K/S]; 1xNethylmaleimide [C34] \\
\hline MGG_08697T0 & SASKSVTVHLGEGYSRTK & 1xGG [S/T/K] \\
\hline MGG_13692T0 & $\begin{array}{c}\text { SPVSPDYDLLSMPPPPSTGITSPLMAD } \\
\text { AGEAEFVDGR }\end{array}$ & 1xGG [T/S]; 1xOxidation [M] \\
\hline MGG_17625T0 & SLKISADSPPR & 1xGG [K3]; 1xLeuArgGlyGly [S1] \\
\hline MGG_05047T0 & $\begin{array}{c}\text { MTAMHLGPPQPSHLLFSPGTSPNAPG } \\
\text { GR }\end{array}$ & 1xPhospho [S/T]; 1xOxidation [M] \\
\hline MGG_08007T0 & DFLVDAPALDTSGPADVVR & 1xPhospho [T/S] \\
\hline MGG_08811T0 & LSSDVSVWASTSWSSVK & 1xPhospho [T/S] \\
\hline MGG_08946T0 & QTSPPPGSYPGAGAGSSRPSR & 1xPhospho [S/T/Y] \\
\hline MGG_08985T0 & STTSSYAALAFVR & 1xPhospho [S/T/Y] \\
\hline MGG_11606T0 & $\begin{array}{c}\text { EVVTMTNTITVTVQSTVTETDANVPAT } \\
\text { TALSFTQR }\end{array}$ & 1xPhospho [T/S]; 1xOxidation [M5] \\
\hline MGG_14575T0 & $\begin{array}{c}\text { MSSPVNMSDPTAVAAMMAEQAAQMA } \\
\text { AVK }\end{array}$ & 1xOxidation [M1]; 1xPhospho [S/T] \\
\hline MGG_00072T0 & TFPDDKPVSVAQVTLGSNGDNKTAK & 1xGG [T/S/K]; 1xPhospho [S/T] \\
\hline MGG_02342T0 & TAAAGASSSAPAPKPSGPK & 1xPhospho [S16]; 1xLeuArgGlyGly [S] \\
\hline \multirow{2}{*}{ MGG_02408T0 } & GSQMNSIDTSNSLIPTLPTTIR & 1xGG [T/S] \\
\hline & SSMVLLTYLDELDAR & 1xPhospho [S]; 1xLeuArgGlyGly [S] \\
\hline MGG_02508T0 & TITHTSLGGTSLPAR & 1xPhospho [S/T]; 1xLeuArgGlyGly [T1] \\
\hline MGG_02988T0 & $\begin{array}{c}\text { HSHVLATFGGLMVVVEANLNALGVAL } \\
\text { AANSSSGPDQQALGK }\end{array}$ & 1xGG [S/K]; 1xPhospho [S] \\
\hline MGG_04685T0 & $\begin{array}{c}\text { VGAGSGSGSGSGFDAAQFGTADTGA } \\
\text { DFIPGTHETAIR }\end{array}$ & 1xGG [S5]; 1xPhospho [S/T] \\
\hline MGG_04929T0 & SSVSSGQAVLDSYPR & 1xGG [S]; 2xPhospho [S] \\
\hline MGG_05798T0 & $\begin{array}{c}\text { MKVSVTLATLAAVVSTVVAAPTAILEA } \\
\text { R }\end{array}$ & 1xGG [T22]; 2xPhospho [T/S] \\
\hline
\end{tabular}




\begin{tabular}{|c|c|c|}
\hline MGG_05938T0 & MMELGVSANLATLASFGGAFR & $\begin{array}{c}\text { 1xGG [S7]; 1xOxidation [M]; 1xPhospho } \\
{[\mathrm{T} / \mathrm{S}]}\end{array}$ \\
\hline MGG_07476T0 & DHFSPTPTVGATGSSPALLSPPPK & 1xPhospho [S/T]; 1xGG [K24] \\
\hline MGG_07975T0 & $\begin{array}{c}\text { TASTMTSAATAAQTAAASSATGAASS } \\
\text { AGAASSAVPAAGAGAK }\end{array}$ & $\begin{array}{c}\text { 1xGG [K/S]; 1xPhospho [S]; } \\
\text { 1xOxidation [M5] }\end{array}$ \\
\hline MGG_08174T0 & TVFLWDVATATTLR & 1xGG [T9]; 2xPhospho [T11; T12] \\
\hline MGG_08211T0 & ARTSTAAGDLDAATPSAVSAAPATK & 1xPhospho [T/S]; 1xLeuArgGlyGly [T/S] \\
\hline MGG_08919T0 & LSISVNDTSSTGYLAK & 1xGG [S/T]; 2xPhospho [T/S/Y] \\
\hline MGG_09185T0 & $\begin{array}{l}\text { NVEPPQGTSAADVAGAFGFGLTESLT } \\
\text { R }\end{array}$ & 1xPhospho [T/S]; 1xGG [S/T] \\
\hline MGG_09262T0 & IYIPSSGGGGAGGATPAGSFR & 1xPhospho [S/T]; 1xLeuArgGlyGly [T/S] \\
\hline MGG_09537T0 & ASYVLETSIVDIR & 1xPhospho [S/Y/T]; 1xGG [T/S] \\
\hline MGG_10001T0 & $\begin{array}{c}\text { FSSVFALSALIQAAVSAPIPSGTGTGN } \\
\text { AVNAITDAATDSTPLK }\end{array}$ & 2xPhospho [S/T]; 1xGG [K/T/S] \\
\hline MGG_10086T0 & LLGVLTLAVSVAAISLDSGVSK & 1xGG [T/K/S]; 2xPhospho [S/T] \\
\hline MGG_11230T0 & $\begin{array}{l}\text { YEAAGGFSLIKGRAVPNGPPSFFPPA } \\
\text { GSAYASDPVAK }\end{array}$ & ; 1XPhospho [Y1] \\
\hline MGG_12714T0 & GQDALVSTVGATGLAGQDNMVR & 1xGG [S7]; 1xPhospho [T/S] \\
\hline \multirow[b]{2}{*}{ MGG_12858T0 } & EIFSSVDGTVPPVTTGATR & 1xLeuArgGlyGly [T18] \\
\hline & $\begin{array}{c}\text { LSGSTQVSNYFTATGTQGPGPISGSA } \\
\text { TAATSRPAETETRGTTSSSR }\end{array}$ & [] \\
\hline MGG_14578T0 & HGEEASVTVLTFSIDTGTPR & 1xGG [T/S]; 2xPhospho [S/T] \\
\hline
\end{tabular}


Supplemental Table 6. List of hypothetical proteins in Supplemental Tables 1-4 with Pfam ${ }^{1}$ annotation compared to Pyricularia oryzae.

\begin{tabular}{|c|c|c|c|}
\hline Accession & Description & Uniprot Entry & PFAM Domains \\
\hline MGG_01364T0 & $\begin{array}{c}\text { MGG_01364 | Magnaporthe } \\
\text { oryzae } 70-15 \text { hypothetical } \\
\text { protein (1012 aa) }\end{array}$ & G4MZ22 & Uncharacterized protein \\
\hline MGG_03223T0 & $\begin{array}{c}\text { MGG_03223 | Magnaporthe } \\
\text { oryzae } 70-15 \text { hypothetical } \\
\text { protein }(2138 \text { aa) }\end{array}$ & G4N9Y5 & Uncharacterized protein \\
\hline MGG_06026T0 & $\begin{array}{c}\text { MGG_06026 | Magnaporthe } \\
\text { oryzae } 70-15 \text { hypothetical } \\
\text { protein (635 aa) }\end{array}$ & G4N4V6 & $\begin{array}{l}\text { PAS domain-containing } \\
\text { protein }\end{array}$ \\
\hline MGG_08290T0 & $\begin{array}{c}\text { MGG_08290 I Magnaporthe } \\
\text { oryzae } 70-15 \text { hypothetical } \\
\text { protein (428 aa) }\end{array}$ & G4MX87 & $\begin{array}{l}\text { Pyr_redox_2 domain- } \\
\text { containing protein }\end{array}$ \\
\hline MGG_09215T0 & $\begin{array}{c}\text { MGG_09215 | Magnaporthe } \\
\text { oryzae } 70-15 \text { hypothetical } \\
\text { protein (1677 aa) }\end{array}$ & G4MPS6 & Uncharacterized protein \\
\hline MGG_01364T0 & $\begin{array}{c}\text { MGG_01364 | Magnaporthe } \\
\text { oryzae } 70-15 \text { hypothetical } \\
\text { protein (1012 aa) }\end{array}$ & G4MZ22 & Uncharacterized protein \\
\hline MGG_02701T0 & $\begin{array}{c}\text { MGG_02701 | Magnaporthe } \\
\text { oryzae } 70-15 \text { hypothetical } \\
\text { protein }(1113 \text { aa) }\end{array}$ & G4NJA2 & Uncharacterized protein \\
\hline MGG_06404T0 & $\begin{array}{c}\text { MGG_06404 | Magnaporthe } \\
\text { oryzae } 70-15 \text { hypothetical } \\
\text { protein (399 aa) }\end{array}$ & G4N719 & $\begin{array}{l}\text { Cytoplasmic tRNA 2- } \\
\text { thiolation protein } 2\end{array}$ \\
\hline MGG_08267T0 & $\begin{array}{c}\text { MGG_08267 | Magnaporthe } \\
\text { oryzae } 70-15 \text { hypothetical } \\
\text { protein (541 aa) }\end{array}$ & G4MXB3 & $\begin{array}{l}\text { FAD-binding PCMH-type } \\
\text { domain-containing protein }\end{array}$ \\
\hline MGG_09394T0 & $\begin{array}{c}\text { MGG_09394 I Magnaporthe } \\
\text { oryzae } 70-15 \text { hypothetical } \\
\text { protein (350 aa) }\end{array}$ & G4NHZO & $\begin{array}{l}\text { Macro domain-containing } \\
\text { protein }\end{array}$ \\
\hline MGG_11100T0 & $\begin{array}{c}\text { MGG_11100 | Magnaporthe } \\
\text { oryzae } 70-15 \text { hypothetical } \\
\text { protein }(656 \text { aa) }\end{array}$ & G4N056 & $\begin{array}{l}\text { DUF4484 domain- } \\
\text { containing protein }\end{array}$ \\
\hline MGG_03286T0 & $\begin{array}{c}\text { MGG_03286 | Magnaporthe } \\
\text { oryzae } 70-15 \text { hypothetical } \\
\text { protein }(1175 \text { aa) }\end{array}$ & G4N9G4 & Uncharacterized protein \\
\hline MGG_00669T0 & $\begin{array}{c}\text { MGG_00669 | Magnaporthe } \\
\text { oryzae } 70-15 \text { hypothetical } \\
\text { protein ( } 555 \text { aa) }\end{array}$ & G4NB01 & Uncharacterized protein \\
\hline MGG_01174T0 & $\begin{array}{c}\text { MGG_01174 | Magnaporthe } \\
\text { oryzae } 70-15 \text { hypothetical } \\
\text { protein (527 aa) }\end{array}$ & G4MWK3 & Uncharacterized protein \\
\hline MGG_01665T0 & $\begin{array}{c}\text { MGG_01665 | Magnaporthe } \\
\text { oryzae } 70-15 \text { hypothetical } \\
\text { protein }(411 \text { aa) }\end{array}$ & A4RK04 & Protein FYV10 \\
\hline MGG_02123T0 & $\begin{array}{c}\text { MGG_02123 | Magnaporthe } \\
\text { oryzae } 70-15 \text { hypothetical } \\
\text { protein (747 aa) }\end{array}$ & G4MNR7 & $\begin{array}{l}\text { AAA domain-containing } \\
\text { protein }\end{array}$ \\
\hline MGG_02483T0 & $\begin{array}{c}\text { MGG_02483 I Magnaporthe } \\
\text { oryzae } 70-15 \text { hypothetical } \\
\text { protein (447 aa) }\end{array}$ & G4MRZ8 & $\begin{array}{l}\text { RNase H2 complex } \\
\text { component }\end{array}$ \\
\hline MGG_02992T0 & $\begin{array}{c}\text { MGG_02992 | Magnaporthe } \\
\text { oryzae } 70-15 \text { hypothetical } \\
\text { protein (605 aa) }\end{array}$ & G4NL24 & G domain-containing protein \\
\hline
\end{tabular}




\begin{tabular}{|c|c|c|c|}
\hline MGG_03292T0 & $\begin{array}{l}\text { MGG_03292 I Magnaporthe } \\
\text { oryzae } 70-15 \text { hypothetical } \\
\text { protein (795 aa) }\end{array}$ & G4N9F8 & $\begin{array}{c}\text { ANK_REP_REGION } \\
\text { domain-containing protein }\end{array}$ \\
\hline MGG_03321T0 & $\begin{array}{c}\text { MGG_03321 I Magnaporthe } \\
\text { oryzae } 70-15 \text { hypothetical } \\
\text { protein (432 aa) }\end{array}$ & G4N973 & Uncharacterized protein \\
\hline MGG_03914T0 & $\begin{array}{l}\text { MGG_03914 | Magnaporthe } \\
\text { oryzae } 70-15 \text { hypothetical } \\
\text { protein ( } 295 \text { aa) }\end{array}$ & G4NH80 & Uncharacterized protein \\
\hline MGG_04146T0 & $\begin{array}{c}\text { MGG_04146 | Magnaporthe } \\
\text { oryzae } 70-15 \text { hypothetical } \\
\text { protein ( } 675 \text { aa) }\end{array}$ & G4NIR2 & ATP-binding domain \\
\hline MGG_04327T0 & $\begin{array}{c}\text { MGG_04327 I Magnaporthe } \\
\text { oryzae } 70-15 \text { hypothetical } \\
\text { protein }(1241 \mathrm{aa})\end{array}$ & G4NGF6 & $\begin{array}{l}\text { MYND-type domain- } \\
\text { containing protein }\end{array}$ \\
\hline MGG_04843T0 & $\begin{array}{c}\text { MGG_04843 | Magnaporthe } \\
\text { oryzae } 70-15 \text { hypothetical } \\
\text { protein (611 aa) }\end{array}$ & G4N2A1 & $\begin{array}{l}\text { Pyriculol/pyriculariol } \\
\text { biosynthesis cluster } \\
\text { transcription factor } 1\end{array}$ \\
\hline MGG_06799T0 & $\begin{array}{c}\text { MGG_06799 | Magnaporthe } \\
\text { oryzae } 70-15 \text { hypothetical } \\
\text { protein (796 aa) }\end{array}$ & G4MM18 & $\begin{array}{l}\text { DUF2828 domain- } \\
\text { containing protein }\end{array}$ \\
\hline MGG_06925T0 & $\begin{array}{c}\text { MGG_06925 | Magnaporthe } \\
\text { oryzae } 70-15 \text { hypothetical } \\
\text { protein (1337 aa) }\end{array}$ & G4MND8 & Cation-transporting ATPase \\
\hline MGG_07573T0 & $\begin{array}{c}\text { MGG_07573 | Magnaporthe } \\
\text { oryzae } 70-15 \text { hypothetical } \\
\text { protein (1060 aa) }\end{array}$ & G4N265 & $\begin{array}{l}\text { Calpain catalytic domain- } \\
\text { containing protein }\end{array}$ \\
\hline MGG_08114T0 & $\begin{array}{c}\text { MGG_08114 | Magnaporthe } \\
\text { oryzae } 70-15 \text { hypothetical } \\
\text { protein (856 aa) }\end{array}$ & G4MYC8 & Uncharacterized protein \\
\hline MGG_08841T0 & $\begin{array}{c}\text { MGG_08841 I Magnaporthe } \\
\text { oryzae } 70-15 \text { hypothetical } \\
\text { protein (1037 aa) }\end{array}$ & G4MV38 & $\begin{array}{l}\text { Cnd3 domain-containing } \\
\text { protein }\end{array}$ \\
\hline MGG_08914T0 & $\begin{array}{c}\text { MGG_08914 I Magnaporthe } \\
\text { oryzae } 70-15 \text { hypothetical } \\
\text { protein (1103 aa) }\end{array}$ & G4MVM7 & $\begin{array}{l}\text { RelA_SpoT domain- } \\
\text { containing protein }\end{array}$ \\
\hline MGG_10157T0 & $\begin{array}{l}\text { MGG_10157 | Magnaporthe } \\
\text { oryzae } 70-15 \text { hypothetical } \\
\text { protein ( } 727 \text { aa) }\end{array}$ & G4MUL6 & $\begin{array}{l}\text { ATP-dependent DNA } \\
\text { helicase II subunit } 2\end{array}$ \\
\hline MGG_10327T0 & $\begin{array}{c}\text { MGG_10327 | Magnaporthe } \\
\text { oryzae } 70-15 \text { hypothetical } \\
\text { protein (730 aa) }\end{array}$ & G4NJT2 & $\begin{array}{l}\text { AAA domain-containing } \\
\text { protein }\end{array}$ \\
\hline MGG_11575T0 & $\begin{array}{c}\text { MGG_11575 | Magnaporthe } \\
\text { oryzae } 70-15 \text { hypothetical } \\
\text { protein ( } 248 \text { aa) }\end{array}$ & G4NC13 & Uncharacterized protein \\
\hline MGG_13058T0 & $\begin{array}{c}\text { MGG_13058 | Magnaporthe } \\
\text { oryzae } 70-15 \text { hypothetical } \\
\text { protein (828 aa) }\end{array}$ & G4MLQ1 & Uncharacterized protein \\
\hline MGG_13191T0 & $\begin{array}{c}\text { MGG_13191 | Magnaporthe } \\
\text { oryzae } 70-15 \text { hypothetical } \\
\text { protein (184 aa) }\end{array}$ & G4N009 & $\begin{array}{l}\mathrm{N} \text {-acetyltransferase domain- } \\
\text { containing protein }\end{array}$ \\
\hline MGG_14270T0 & $\begin{array}{c}\text { MGG_14270 | Magnaporthe } \\
\text { oryzae } 70-15 \text { hypothetical } \\
\text { protein ( } 366 \text { aa) }\end{array}$ & G4MLG2 & Uncharacterized protein \\
\hline MGG_16442T0 & $\begin{array}{c}\text { MGG_16442 | Magnaporthe } \\
\text { oryzae } 70-15 \text { hypothetical } \\
\text { protein ( } 277 \text { aa) }\end{array}$ & G4MP08 & $\begin{array}{c}\text { Protein-lysine N- } \\
\text { methyltransferase EFM4 }\end{array}$ \\
\hline
\end{tabular}




\begin{tabular}{|c|c|c|c|}
\hline MGG_17680T0 & $\begin{array}{l}\text { MGG_17680 | Magnaporthe } \\
\text { oryzae } 70-15 \text { hypothetical } \\
\text { protein (117 aa) }\end{array}$ & G4NIQ4 & Uncharacterized protein \\
\hline MGG_17701T0 & $\begin{array}{c}\text { MGG_17701 I Magnaporthe } \\
\text { oryzae } 70-15 \text { hypothetical } \\
\text { protein (357 aa) }\end{array}$ & G4NGR7 & Elongator subunit Iki1 \\
\hline MGG_02055T0 & $\begin{array}{c}\text { MGG_02055 | Magnaporthe } \\
\text { oryzae } 70-15 \text { hypothetical } \\
\text { protein ( } 616 \text { aa) }\end{array}$ & G4MN79 & Uncharacterized protein \\
\hline MGG_00070T0 & $\begin{array}{c}\text { MGG_00070 | Magnaporthe } \\
\text { oryzae } 70-15 \text { hypothetical } \\
\text { protein ( } 235 \text { aa) }\end{array}$ & G4NER5 & $\begin{array}{l}\mathrm{Zn}(2)-\mathrm{C6} \text { fungal-type } \\
\text { domain-containing protein }\end{array}$ \\
\hline MGG_00143T0 & $\begin{array}{l}\text { MGG_00143 | Magnaporthe } \\
\text { oryzae } 70-15 \text { hypothetical } \\
\text { protein (396 aa) }\end{array}$ & G4NE73 & $\begin{array}{l}\text { zf-LYAR domain-containing } \\
\text { protein }\end{array}$ \\
\hline MGG_00851T0 & $\begin{array}{c}\text { MGG_00851 I Magnaporthe } \\
\text { oryzae } 70-15 \text { hypothetical } \\
\text { protein ( } 426 \text { aa) }\end{array}$ & G4NE08 & $\begin{array}{l}\text { Ribosome biogenesis } \\
\text { protein TSR3 }\end{array}$ \\
\hline MGG_01069T0 & $\begin{array}{c}\text { MGG_01069 | Magnaporthe } \\
\text { oryzae } 70-15 \text { hypothetical } \\
\text { protein (104 aa) }\end{array}$ & G4NCI9 & Uncharacterized protein \\
\hline MGG_01305T0 & $\begin{array}{c}\text { MGG_01305 | Magnaporthe } \\
\text { oryzae } 70-15 \text { hypothetical } \\
\text { protein (144 aa) }\end{array}$ & G4MYJ6 & $\begin{array}{l}\text { UCR_hinge domain- } \\
\text { containing protein }\end{array}$ \\
\hline MGG_02109T0 & $\begin{array}{c}\text { MGG_02109 | Magnaporthe } \\
\text { oryzae } 70-15 \text { hypothetical } \\
\text { protein (92 aa) }\end{array}$ & G4MNQ1 & Uncharacterized protein \\
\hline MGG_02537T0 & $\begin{array}{c}\text { MGG_02537 | Magnaporthe } \\
\text { oryzae } 70-15 \text { hypothetical } \\
\text { protein (869 aa) }\end{array}$ & G4NK40 & Uncharacterized protein \\
\hline MGG_03000T0 & $\begin{array}{l}\text { MGG_03000 | Magnaporthe } \\
\text { oryzae } 70-15 \text { hypothetical } \\
\text { protein (592 aa) }\end{array}$ & G5EI50 & Uncharacterized protein \\
\hline MGG_03462T0 & $\begin{array}{l}\text { MGG_03462 I Magnaporthe } \\
\text { oryzae } 70-15 \text { hypothetical } \\
\text { protein (585 aa) }\end{array}$ & G4N898 & $\begin{array}{l}\text { Amidase domain-containing } \\
\text { protein }\end{array}$ \\
\hline MGG_03863T0 & $\begin{array}{l}\text { MGG_03863 | Magnaporthe } \\
\text { oryzae } 70-15 \text { hypothetical } \\
\text { protein (187 aa) }\end{array}$ & G4NHF2 & Uncharacterized protein \\
\hline MGG_04344T0 & $\begin{array}{c}\text { MGG_04344 | Magnaporthe } \\
\text { oryzae } 70-15 \text { hypothetical } \\
\text { protein (563 aa) }\end{array}$ & G4NGD7 & Uncharacterized protein \\
\hline MGG_04677T0 & $\begin{array}{c}\text { MGG_04677 I Magnaporthe } \\
\text { oryzae } 70-15 \text { hypothetical } \\
\text { protein ( } 646 \text { aa) }\end{array}$ & G4MRC2 & $\begin{array}{c}\text { Glyco_trans_2-like domain- } \\
\text { containing protein }\end{array}$ \\
\hline MGG_04736T0 & $\begin{array}{c}\text { MGG_04736 | Magnaporthe } \\
\text { oryzae } 70-15 \text { hypothetical } \\
\text { protein }(304 \text { aa) }\end{array}$ & G4MQW1 & $\begin{array}{l}\text { F420_oxidored domain- } \\
\text { containing protein }\end{array}$ \\
\hline MGG_05674T0 & $\begin{array}{c}\text { MGG_05674 | Magnaporthe } \\
\text { oryzae } 70-15 \text { hypothetical } \\
\text { protein ( } 411 \text { aa) }\end{array}$ & G4MP12 & Magnesium transporter \\
\hline MGG_05766T0 & $\begin{array}{c}\text { MGG_05766 | Magnaporthe } \\
\text { oryzae } 70-15 \text { hypothetical } \\
\text { protein ( } 288 \text { aa) }\end{array}$ & G4MPZ2 & Uncharacterized protein \\
\hline MGG_06285T0 & $\begin{array}{c}\text { MGG_06285 | Magnaporthe } \\
\text { oryzae } 70-15 \text { hypothetical } \\
\text { protein ( } 978 \text { aa) }\end{array}$ & G4N881 & $\begin{array}{l}\text { Homeobox domain- } \\
\text { containing protein }\end{array}$ \\
\hline
\end{tabular}




\begin{tabular}{|c|c|c|c|}
\hline MGG_06545T0 & $\begin{array}{c}\text { MGG_06545 | Magnaporthe } \\
\text { oryzae } 70-15 \text { hypothetical } \\
\text { protein ( } 815 \text { aa) }\end{array}$ & G4N6K9 & Uncharacterized protein \\
\hline MGG_06906T0 & $\begin{array}{c}\text { MGG_06906 | Magnaporthe } \\
\text { oryzae } 70-15 \text { hypothetical } \\
\text { protein (568 aa) }\end{array}$ & G4MN06 & Zinc carboxypeptidase \\
\hline MGG_07369T0 & $\begin{array}{c}\text { MGG_07369 | Magnaporthe } \\
\text { oryzae } 70-15 \text { hypothetical } \\
\text { protein (412 aa) }\end{array}$ & G4MVH7 & Uncharacterized protein \\
\hline MGG_07394T0 & $\begin{array}{c}\text { MGG_07394 | Magnaporthe } \\
\text { oryzae } 70-15 \text { hypothetical } \\
\text { protein (116 aa) }\end{array}$ & G4N0C7 & $\begin{array}{l}\text { DNA-directed RNA } \\
\text { polymerase subunit }\end{array}$ \\
\hline MGG_08083T0 & $\begin{array}{l}\text { MGG_08083 I Magnaporthe } \\
\text { oryzae } 70-15 \text { hypothetical } \\
\text { protein ( } 546 \text { aa) }\end{array}$ & G4MY96 & GLE1-like protein \\
\hline MGG_08201T0 & $\begin{array}{c}\text { MGG_08201 | Magnaporthe } \\
\text { oryzae } 70-15 \text { hypothetical } \\
\text { protein (137 aa) }\end{array}$ & G4MZA0 & $\begin{array}{l}\text { GFA domain-containing } \\
\text { protein }\end{array}$ \\
\hline MGG_08308T0 & $\begin{array}{c}\text { MGG_08308 | Magnaporthe } \\
\text { oryzae } 70-15 \text { hypothetical } \\
\text { protein ( } 282 \text { aa) }\end{array}$ & G4MWV7 & $\begin{array}{l}\text { Nuclear pore complex } \\
\text { component }\end{array}$ \\
\hline MGG_08577T0 & $\begin{array}{c}\text { MGG_08577 | Magnaporthe } \\
\text { oryzae } 70-15 \text { hypothetical } \\
\text { protein (432 aa) }\end{array}$ & G4N658 & $\begin{array}{l}\text { Glyco_hydro_cc domain- } \\
\text { containing protein }\end{array}$ \\
\hline MGG_08795T0 & $\begin{array}{l}\text { MGG_08795 | Magnaporthe } \\
\text { oryzae } 70-15 \text { hypothetical } \\
\text { protein (595 aa) }\end{array}$ & G4NFK3 & Cytochrome P450 \\
\hline MGG_10274T0 & $\begin{array}{c}\text { MGG_10274 | Magnaporthe } \\
\text { oryzae } 70-15 \text { hypothetical } \\
\text { protein ( } 255 \text { aa) }\end{array}$ & Q2KEJ5 & short-chain dehydrogenase \\
\hline MGG_11130T0 & $\begin{array}{l}\text { MGG_11130 | Magnaporthe } \\
\text { oryzae } 70-15 \text { hypothetical } \\
\text { protein }(713 \text { aa) }\end{array}$ & G4MW77 & Uncharacterized protein \\
\hline MGG_12745T0 & $\begin{array}{c}\text { MGG_12745 | Magnaporthe } \\
\text { oryzae } 70-15 \text { hypothetical } \\
\text { protein (507 aa) }\end{array}$ & G4N9W5 & $\begin{array}{l}\text { tRNA_int_end_N2 domain- } \\
\text { containing protein }\end{array}$ \\
\hline MGG_13774T0 & $\begin{array}{l}\text { MGG_13774 | Magnaporthe } \\
\text { oryzae } 70-15 \text { hypothetical } \\
\text { protein ( } 340 \text { aa) }\end{array}$ & G4MR90 & general transcription factor \\
\hline MGG_14678T0 & $\begin{array}{c}\text { MGG_14678 | Magnaporthe } \\
\text { oryzae } 70-15 \text { hypothetical } \\
\text { protein (409 aa) }\end{array}$ & G4NBT7 & $\begin{array}{l}\text { DUF1640 domain- } \\
\text { containing protein }\end{array}$ \\
\hline MGG_15688T0 & $\begin{array}{c}\text { MGG_15688 | Magnaporthe } \\
\text { oryzae } 70-15 \text { hypothetical } \\
\text { protein (692 aa) }\end{array}$ & G4MZ51 & $\begin{array}{l}\text { Amino_oxidase domain- } \\
\text { containing protein }\end{array}$ \\
\hline MGG_16374T0 & $\begin{array}{c}\text { MGG_16374 | Magnaporthe } \\
\text { oryzae } 70-15 \text { hypothetical } \\
\text { protein (351 aa) }\end{array}$ & G4MM59 & $\begin{array}{l}\text { NAD(P)-bd_dom domain- } \\
\text { containing protein }\end{array}$ \\
\hline MGG_17476T0 & $\begin{array}{c}\text { MGG_17476 | Magnaporthe } \\
\text { oryzae } 70-15 \text { hypothetical } \\
\text { protein ( } 253 \text { aa) }\end{array}$ & G4NCY8 & $\begin{array}{l}\text { DLH domain-containing } \\
\text { protein }\end{array}$ \\
\hline MGG_17595T0 & $\begin{array}{c}\text { MGG_17595 | Magnaporthe } \\
\text { oryzae } 70-15 \text { hypothetical } \\
\text { protein ( } 510 \text { aa) }\end{array}$ & G4NG27 & $\begin{array}{l}\text { DAO domain-containing } \\
\text { protein }\end{array}$ \\
\hline MGG_17713T0 & $\begin{array}{c}\text { MGG_17713 | Magnaporthe } \\
\text { oryzae } 70-15 \text { hypothetical } \\
\text { protein (637 aa) }\end{array}$ & G4NGY9 & Uncharacterized protein \\
\hline
\end{tabular}




\begin{tabular}{|c|c|c|c|}
\hline MGG_17829T0 & $\begin{array}{c}\text { MGG_17829 | Magnaporthe } \\
\text { oryzae } 70-15 \text { hypothetical } \\
\text { protein ( } 363 \text { aa) }\end{array}$ & G4NID5 & $\begin{array}{l}\text { Malate/L-lactate } \\
\text { dehydrogenase }\end{array}$ \\
\hline MGG_01080T0 & $\begin{array}{c}\text { MGG_01080 I Magnaporthe } \\
\text { oryzae } 70-15 \text { hypothetical } \\
\text { protein (1465 aa) }\end{array}$ & $\mathrm{G} 4 \mathrm{NCH} 7$ & $\begin{array}{l}\text { Chromo domain-containing } \\
\text { protein }\end{array}$ \\
\hline MGG_07960T0 & $\begin{array}{c}\text { MGG_07960 | Magnaporthe } \\
\text { oryzae } 70-15 \text { hypothetical } \\
\text { protein (401 aa) }\end{array}$ & G4N2U9 & Uncharacterized protein \\
\hline MGG_08912T0 & $\begin{array}{c}\text { MGG_08912 I Magnaporthe } \\
\text { oryzae } 70-15 \text { hypothetical } \\
\text { protein (446 aa) }\end{array}$ & G4MVM5 & $\begin{array}{l}\text { RING-type domain- } \\
\text { containing protein }\end{array}$ \\
\hline MGG_09384T0 & $\begin{array}{c}\text { MGG_09384 | Magnaporthe } \\
\text { oryzae } 70-15 \text { hypothetical } \\
\text { protein ( } 514 \text { aa) }\end{array}$ & G4NI00 & Uncharacterized protein \\
\hline MGG_09710T0 & $\begin{array}{c}\text { MGG_09710 | Magnaporthe } \\
\text { oryzae } 70-15 \text { hypothetical } \\
\text { protein ( } 294 \text { aa) }\end{array}$ & G4NAI4 & Uncharacterized protein \\
\hline MGG_12009T0 & $\begin{array}{c}\text { MGG_12009 | Magnaporthe } \\
\text { oryzae } 70-15 \text { hypothetical } \\
\text { protein ( } 858 \text { aa) }\end{array}$ & G4NI20 & Uncharacterized protein \\
\hline MGG_16007T0 & $\begin{array}{c}\text { MGG_16007 / Magnaporthe } \\
\text { oryzae } 70-15 \text { hypothetical } \\
\text { protein ( } 200 \text { aa) }\end{array}$ & G4MMU3 & Uncharacterized protein \\
\hline MGG_17263T0 & $\begin{array}{l}\text { MGG_17263 | Magnaporthe } \\
\text { oryzae } 70-15 \text { hypothetical } \\
\text { protein (308 aa) }\end{array}$ & G4N9P9 & Uncharacterized protein \\
\hline MGG_01996T1 & $\begin{array}{c}\text { MGG_01996 | Magnaporthe } \\
\text { oryzae } 70-15 \text { hypothetical } \\
\text { protein (1015 aa) }\end{array}$ & G4MME0 & Uncharacterized protein \\
\hline MGG_06699T0 & $\begin{array}{c}\text { MGG_06699 | Magnaporthe } \\
\text { oryzae } 70-15 \text { hypothetical } \\
\text { protein (480 aa) }\end{array}$ & G4ML61 & Uncharacterized protein \\
\hline MGG_07599T0 & $\begin{array}{c}\text { MGG_07599 | Magnaporthe } \\
\text { oryzae } 70-15 \text { hypothetical } \\
\text { protein (141 aa) }\end{array}$ & G4N2K0 & Uncharacterized protein \\
\hline MGG_14758T0 & $\begin{array}{c}\text { MGG_14758 / Magnaporthe } \\
\text { oryzae } 70-15 \text { hypothetical } \\
\text { protein (190 aa) }\end{array}$ & G4MV81 & Uncharacterized protein \\
\hline MGG_00944T0 & $\begin{array}{c}\text { MGG_00944 | Magnaporthe } \\
\text { oryzae } 70-15 \text { hypothetical } \\
\text { protein (480 aa) }\end{array}$ & G4NDD3 & Uncharacterized protein \\
\hline MGG_03624T0 & $\begin{array}{c}\text { MGG_03624 I Magnaporthe } \\
\text { oryzae } 70-15 \text { hypothetical } \\
\text { protein ( } 230 \text { aa) }\end{array}$ & G4N735 & Uncharacterized protein \\
\hline MGG_04329T0 & $\begin{array}{c}\text { MGG_04329 | Magnaporthe } \\
\text { oryzae } 70-15 \text { hypothetical } \\
\text { protein (516 aa) }\end{array}$ & G4NGF4 & $\begin{array}{l}\text { MFS domain-containing } \\
\text { protein }\end{array}$ \\
\hline MGG_07817T0 & $\begin{array}{c}\text { MGG_07817 | Magnaporthe } \\
\text { oryzae } 70-15 \text { hypothetical } \\
\text { protein (602 aa) }\end{array}$ & G4N1F9 & Uncharacterized protein \\
\hline MGG_07972T0 & $\begin{array}{c}\text { MGG_07972 | Magnaporthe } \\
\text { oryzae } 70-15 \text { hypothetical } \\
\text { protein ( } 292 \text { aa) }\end{array}$ & G4N2W3 & Uncharacterized protein \\
\hline MGG_08348T0 & $\begin{array}{c}\text { MGG_08348 / Magnaporthe } \\
\text { oryzae } 70-15 \text { hypothetical } \\
\text { protein ( } 82 \text { aa) }\end{array}$ & G4MWE7 & Uncharacterized protein \\
\hline
\end{tabular}




\begin{tabular}{|c|c|c|c|}
\hline MGG_09236T0 & $\begin{array}{c}\text { MGG_09236 | Magnaporthe } \\
\text { oryzae } 70-15 \text { hypothetical } \\
\text { protein (857 aa) }\end{array}$ & G4MPU9 & Uncharacterized protein \\
\hline MGG_00052T0 & $\begin{array}{c}\text { MGG_00052 I Magnaporthe } \\
\text { oryzae } 70-15 \text { hypothetical } \\
\text { protein ( } 225 \text { aa) }\end{array}$ & G4NET4 & Uncharacterized protein \\
\hline MGG_00521T0 & $\begin{array}{c}\text { MGG_00521 | Magnaporthe } \\
\text { oryzae } 70-15 \text { hypothetical } \\
\text { protein ( } 874 \text { aa) }\end{array}$ & G4NBP4 & $\begin{array}{l}\text { Tr-type G domain- } \\
\text { containing protein }\end{array}$ \\
\hline MGG_00532T0 & $\begin{array}{c}\text { MGG_00532 I Magnaporthe } \\
\text { oryzae } 70-15 \text { hypothetical } \\
\text { protein (530 aa) }\end{array}$ & G4NBI3 & $\begin{array}{c}\text { G_PROTEIN_RECEP_F2_4 } \\
\text { domain-containing protein }\end{array}$ \\
\hline MGG_01814T0 & $\begin{array}{l}\text { MGG_01814 I Magnaporthe } \\
\text { oryzae } 70-15 \text { hypothetical } \\
\text { protein (460 aa) }\end{array}$ & G4MW59 & Uncharacterized protein \\
\hline MGG_03347T0 & $\begin{array}{c}\text { MGG_03347 | Magnaporthe } \\
\text { oryzae } 70-15 \text { hypothetical } \\
\text { protein ( } 275 \text { aa) }\end{array}$ & G4N8Z2 & Uncharacterized protein \\
\hline MGG_05022T0 & $\begin{array}{c}\text { MGG_05022 | Magnaporthe } \\
\text { oryzae } 70-15 \text { hypothetical } \\
\text { protein ( } 322 \text { aa) }\end{array}$ & G4N3U8 & $\begin{array}{l}\text { NmrA domain-containing } \\
\text { protein }\end{array}$ \\
\hline MGG_05033T0 & $\begin{array}{c}\text { MGG_05033 | Magnaporthe } \\
\text { oryzae } 70-15 \text { hypothetical } \\
\text { protein ( } 743 \text { aa) }\end{array}$ & G4N3W1 & $\begin{array}{c}\mathrm{Zn}(2)-\mathrm{C} 6 \text { fungal-type } \\
\text { domain-containing protein }\end{array}$ \\
\hline MGG_05139T0 & $\begin{array}{c}\text { MGG_05139 | Magnaporthe } \\
\text { oryzae } 70-15 \text { hypothetical } \\
\text { protein (477 aa) }\end{array}$ & G4N4P7 & Uncharacterized protein \\
\hline MGG_05272T0 & $\begin{array}{c}\text { MGG_05272 | Magnaporthe } \\
\text { oryzae } 70-15 \text { hypothetical } \\
\text { protein ( } 785 \text { aa) }\end{array}$ & G4N5N4 & $\begin{array}{l}\text { Microtubule associated } \\
\text { protein }\end{array}$ \\
\hline MGG_05756T0 & $\begin{array}{c}\text { MGG_05756 | Magnaporthe } \\
\text { oryzae } 70-15 \text { hypothetical } \\
\text { protein ( } 250 \text { aa) }\end{array}$ & G4MPX8 & $\begin{array}{l}\text { RNA cap guanine-N2 } \\
\text { methyltransferase }\end{array}$ \\
\hline MGG_06893T0 & $\begin{array}{c}\text { MGG_06893 | Magnaporthe } \\
\text { oryzae } 70-15 \text { hypothetical } \\
\text { protein (548 aa) }\end{array}$ & G4MMY7 & $\begin{array}{l}\text { DUF2838 domain- } \\
\text { containing protein }\end{array}$ \\
\hline MGG_10156T0 & $\begin{array}{l}\text { MGG_10156 | Magnaporthe } \\
\text { oryzae } 70-15 \text { hypothetical } \\
\text { protein (185 aa) }\end{array}$ & G4MUA7 & $\begin{array}{l}\text { DUF4149 domain- } \\
\text { containing protein }\end{array}$ \\
\hline MGG_10252T0 & $\begin{array}{c}\text { MGG_10252 | Magnaporthe } \\
\text { oryzae } 70-15 \text { hypothetical } \\
\text { protein (487 aa) }\end{array}$ & Q2KEM0 & $\begin{array}{l}\text { upin Super family domain } \\
\text { containing protein }\end{array}$ \\
\hline MGG_12124T0 & $\begin{array}{c}\text { MGG_12124 | Magnaporthe } \\
\text { oryzae } 70-15 \text { hypothetical } \\
\text { protein (54 aa) }\end{array}$ & G4NH05 & $\begin{array}{l}\text { TOM domain containing } \\
\text { protein }\end{array}$ \\
\hline MGG_13455T0 & $\begin{array}{l}\text { MGG_13455 | Magnaporthe } \\
\text { oryzae } 70-15 \text { hypothetical } \\
\text { protein (469 aa) }\end{array}$ & G4N3E1 & $\begin{array}{l}\text { Mannan endo-1,6-alpha- } \\
\text { mannosidase }\end{array}$ \\
\hline MGG_16418T0 & $\begin{array}{c}\text { MGG_16418 | Magnaporthe } \\
\text { oryzae } 70-15 \text { hypothetical } \\
\text { protein ( } 220 \text { aa) }\end{array}$ & G4MN62 & Uncharacterized protein \\
\hline MGG_17677T0 & $\begin{array}{c}\text { MGG_17677 | Magnaporthe } \\
\text { oryzae } 70-15 \text { hypothetical } \\
\text { protein ( } 618 \text { aa) }\end{array}$ & G4NIP9 & $\begin{array}{l}\text { MFS domain-containing } \\
\text { protein }\end{array}$ \\
\hline MGG_17979T0 & $\begin{array}{c}\text { MGG_17979 | Magnaporthe } \\
\text { oryzae } 70-15 \text { hypothetical } \\
\text { protein ( } 145 \text { aa) }\end{array}$ & G4NJ62 & $\begin{array}{l}\text { DUF2076 domain- } \\
\text { containing protein }\end{array}$ \\
\hline
\end{tabular}




\begin{tabular}{|c|c|c|c|}
\hline MGG_02114T0 & $\begin{array}{c}\text { MGG_02114 | Magnaporthe } \\
\text { oryzae } 70-15 \text { hypothetical } \\
\text { protein ( } 813 \text { aa) }\end{array}$ & G4MNQ6 & $\begin{array}{c}\text { Dynamin GTPase effector } \\
\text { domain }\end{array}$ \\
\hline MGG_02377T0 & $\begin{array}{c}\text { MGG_02377 I Magnaporthe } \\
\text { oryzae } 70-15 \text { hypothetical } \\
\text { protein ( } 884 \text { aa) }\end{array}$ & G4MR05 & $\begin{array}{c}\mathrm{Zn}(2)-\mathrm{C} 6 \text { fungal-type } \\
\text { domain-containing protein }\end{array}$ \\
\hline MGG_06430T0 & $\begin{array}{c}\text { MGG_06430 | Magnaporthe } \\
\text { oryzae } 70-15 \text { hypothetical } \\
\text { protein ( } 565 \text { aa) }\end{array}$ & G4N7A8 & $\begin{array}{l}\text { Lon protease domain } \\
\text { containing protein }\end{array}$ \\
\hline MGG_07598T0 & $\begin{array}{c}\text { MGG_07598 | Magnaporthe } \\
\text { oryzae } 70-15 \text { hypothetical } \\
\text { protein ( } 200 \text { aa) }\end{array}$ & G4N2J9 & Uncharacterized protein \\
\hline MGG_07905T0 & $\begin{array}{c}\text { MGG_07905 I Magnaporthe } \\
\text { oryzae } 70-15 \text { hypothetical } \\
\text { protein (1974 aa) }\end{array}$ & G4N2D5 & Uncharacterized protein \\
\hline MGG_08467T0 & $\begin{array}{c}\text { MGG_08467 | Magnaporthe } \\
\text { oryzae } 70-15 \text { hypothetical } \\
\text { protein ( } 412 \text { aa) }\end{array}$ & G4NAL0 & Uncharacterized protein \\
\hline MGG_08697T0 & $\begin{array}{c}\text { MGG_08697 I Magnaporthe } \\
\text { oryzae } 70-15 \text { hypothetical } \\
\text { protein (1249 aa) }\end{array}$ & G4NFV9 & Uncharacterized protein \\
\hline MGG_13692T0 & $\begin{array}{c}\text { MGG_13692 | Magnaporthe } \\
\text { oryzae } 70-15 \text { hypothetical } \\
\text { protein (87 aa) }\end{array}$ & G4MMV8 & Uncharacterized protein \\
\hline MGG_17625T0 & $\begin{array}{c}\text { MGG_17625 | Magnaporthe } \\
\text { oryzae } 70-15 \text { hypothetical } \\
\text { protein }(814 \mathrm{aa})\end{array}$ & G4NGC3 & Uncharacterized protein \\
\hline MGG_05047T0 & $\begin{array}{c}\text { MGG_05047 | Magnaporthe } \\
\text { oryzae } 70-15 \text { hypothetical } \\
\text { protein (883 aa) }\end{array}$ & G4N429 & Uncharacterized protein \\
\hline MGG_08007T0 & $\begin{array}{l}\text { MGG_08007 I Magnaporthe } \\
\text { oryzae } 70-15 \text { hypothetical } \\
\text { protein ( } 254 \text { aa) }\end{array}$ & G4MX53AB & $\begin{array}{l}\text { hydrolase-1 domain- } \\
\text { containing protein }\end{array}$ \\
\hline MGG_08811T0 & $\begin{array}{c}\text { MGG_08811 I Magnaporthe } \\
\text { oryzae } 70-15 \text { hypothetical } \\
\text { protein (320 aa) }\end{array}$ & G4NFI6 & Uncharacterized protein \\
\hline MGG_08946T0 & $\begin{array}{l}\text { MGG_08946 | Magnaporthe } \\
\text { oryzae } 70-15 \text { hypothetical } \\
\text { protein ( } 237 \text { aa) }\end{array}$ & G4MW23 & Uncharacterized protein \\
\hline MGG_11606T0 & $\begin{array}{c}\text { MGG_11606 | Magnaporthe } \\
\text { oryzae } 70-15 \text { hypothetical } \\
\text { protein (343 aa) }\end{array}$ & G4ND76 & Uncharacterized protein \\
\hline MGG_14575T0 & $\begin{array}{c}\text { MGG_14575 | Magnaporthe } \\
\text { oryzae } 70-15 \text { hypothetical } \\
\text { protein ( } 514 \text { aa) }\end{array}$ & G4MQY6 & Uncharacterized protein \\
\hline MGG_02342T0 & $\begin{array}{c}\text { MGG_02342 | Magnaporthe } \\
\text { oryzae } 70-15 \text { hypothetical } \\
\text { protein (853 aa) }\end{array}$ & G4MQK7 & Uncharacterized protein \\
\hline MGG_02408T0 & $\begin{array}{c}\text { MGG_02408 | Magnaporthe } \\
\text { oryzae } 70-15 \text { hypothetical } \\
\text { protein (929 aa) }\end{array}$ & G4MRF4 & $\begin{array}{l}\mathrm{Zn}(2)-\mathrm{C} 6 \text { fungal-type } \\
\text { domain-containing protein }\end{array}$ \\
\hline MGG_02508T0 & $\begin{array}{c}\text { MGG_02508 | Magnaporthe } \\
\text { oryzae } 70-15 \text { hypothetical } \\
\text { protein ( } 269 \text { aa) }\end{array}$ & G4MKB2 & $\begin{array}{l}\text { Tyrosinase_Cu-bd domain- } \\
\text { containing protein }\end{array}$ \\
\hline MGG_02988T0 & $\begin{array}{c}\text { MGG_02988 | Magnaporthe } \\
\text { oryzae } 70-15 \text { hypothetical } \\
\text { protein ( } 384 \text { aa) }\end{array}$ & G4NL30 & Uncharacterized protein \\
\hline
\end{tabular}




\begin{tabular}{|c|c|c|c|}
\hline MGG_04685T0 & $\begin{array}{c}\text { MGG_04685 | Magnaporthe } \\
\text { oryzae } 70-15 \text { hypothetical } \\
\text { protein (1459 aa) }\end{array}$ & G4MRB0 & $\begin{array}{l}\text { MIT domain-containing } \\
\text { protein }\end{array}$ \\
\hline MGG_04929T0 & $\begin{array}{c}\text { MGG_04929 | Magnaporthe } \\
\text { oryzae } 70-15 \text { hypothetical } \\
\text { protein ( } 750 \text { aa) }\end{array}$ & G4N357 & Uncharacterized protein \\
\hline MGG_05798T0 & $\begin{array}{l}\text { MGG_05798 | Magnaporthe } \\
\text { oryzae } 70-15 \text { hypothetical } \\
\text { protein ( } 217 \text { aa) }\end{array}$ & G4NOH2 & Cutinase \\
\hline MGG_07476T0 & $\begin{array}{c}\text { MGG_07476 | Magnaporthe } \\
\text { oryzae } 70-15 \text { hypothetical } \\
\text { protein ( } 872 \text { aa) }\end{array}$ & G4N196 & Eisosome protein \\
\hline MGG_07975T0 & $\begin{array}{l}\text { MGG_07975 I Magnaporthe } \\
\text { oryzae } 70-15 \text { hypothetical } \\
\text { protein (193 aa) }\end{array}$ & G4N2W6 & Uncharacterized protein \\
\hline MGG_08211T0 & $\begin{array}{c}\text { MGG_08211 | Magnaporthe } \\
\text { oryzae } 70-15 \text { hypothetical } \\
\text { protein ( } 572 \text { aa) }\end{array}$ & G4MZM2 & Mis12-Mtw1 protein \\
\hline MGG_09185T0 & $\begin{array}{c}\text { MGG_09185 | Magnaporthe } \\
\text { oryzae } 70-15 \text { hypothetical } \\
\text { protein (1228 aa) }\end{array}$ & G4MPD1 & Uncharacterized protein \\
\hline MGG_10001T0 & $\begin{array}{c}\text { MGG_10001 | Magnaporthe } \\
\text { oryzae } 70-15 \text { hypothetical } \\
\text { protein ( } 265 \text { aa) }\end{array}$ & G4N9E5 & Uncharacterized protein \\
\hline MGG_10086T0 & $\begin{array}{c}\text { MGG_10086 | Magnaporthe } \\
\text { oryzae } 70-15 \text { hypothetical } \\
\text { protein (129 aa) }\end{array}$ & - & \\
\hline MGG_11230T0 & $\begin{array}{c}\text { MGG_11230 | Magnaporthe } \\
\text { oryzae } 70-15 \text { hypothetical } \\
\text { protein (601 aa) }\end{array}$ & G4MYM5 & Uncharacterized protein \\
\hline MGG_12714T0 & $\begin{array}{l}\text { MGG_12714 | Magnaporthe } \\
\text { oryzae } 70-15 \text { hypothetical } \\
\text { protein ( } 310 \text { aa) }\end{array}$ & G4N8W7 & $\begin{array}{l}\text { NmrA domain-containing } \\
\text { protein }\end{array}$ \\
\hline MGG_12858T0 & $\begin{array}{l}\text { MGG_12858 | Magnaporthe } \\
\text { oryzae } 70-15 \text { hypothetical } \\
\text { protein ( } 254 \text { aa) }\end{array}$ & G4N840 & Uncharacterized protein \\
\hline MGG_14578T0 & $\begin{array}{l}\text { MGG_14578 | Magnaporthe } \\
\text { oryzae } 70-15 \text { hypothetical } \\
\text { protein ( } 285 \text { aa) }\end{array}$ & G4MRH4 & Uncharacterized protein \\
\hline MGG_00199T0 & $\begin{array}{c}\text { MGG_00199 | Magnaporthe } \\
\text { oryzae } 70-15 \text { hypothetical } \\
\text { protein (1296 aa) }\end{array}$ & $\begin{array}{l}\text { RasGEF domain } \\
\text { containing protein }\end{array}$ & $\begin{array}{l}\text { RasGEF domain containing } \\
\text { protein }\end{array}$ \\
\hline MGG_00569T0 & $\begin{array}{c}\text { MGG_00569 | Magnaporthe } \\
\text { oryzae } 70-15 \text { hypothetical } \\
\text { protein ( } 772 \text { aa) }\end{array}$ & $\begin{array}{l}\text { HET domain- } \\
\text { containing protein }\end{array}$ & $\begin{array}{l}\text { HET domain-containing } \\
\text { protein }\end{array}$ \\
\hline MGG_03162T0 & $\begin{array}{c}\text { MGG_03162 I Magnaporthe } \\
\text { oryzae } 70-15 \text { hypothetical } \\
\text { protein }(1010 \mathrm{aa})\end{array}$ & $\begin{array}{l}\text { Uncharacterized } \\
\text { protein }\end{array}$ & Uncharacterized protein \\
\hline MGG_03567T0 & $\begin{array}{c}\text { MGG_03567 | Magnaporthe } \\
\text { oryzae } 70-15 \text { hypothetical } \\
\text { protein (317 aa) }\end{array}$ & $\begin{array}{l}\text { Uncharacterized } \\
\text { protein }\end{array}$ & Uncharacterized protein \\
\hline MGG_04196T0 & $\begin{array}{c}\text { MGG_04196 | Magnaporthe } \\
\text { oryzae } 70-15 \text { hypothetical } \\
\text { protein ( } 1132 \text { aa) }\end{array}$ & $\begin{array}{c}\text { Rab-GAP TBC } \\
\text { domain-containing } \\
\text { protein }\end{array}$ & $\begin{array}{l}\text { Rab-GAP TBC domain- } \\
\text { containing protein }\end{array}$ \\
\hline MGG_06010T0 & $\begin{array}{c}\text { MGG_06010 | Magnaporthe } \\
\text { oryzae } 70-15 \text { hypothetical } \\
\text { protein (125 aa) }\end{array}$ & $\begin{array}{l}\text { DUF952 domain } \\
\text { containing protein }\end{array}$ & $\begin{array}{l}\text { DUF952 domain containing } \\
\text { protein }\end{array}$ \\
\hline
\end{tabular}




\begin{tabular}{|c|c|c|c|}
\hline MGG_08341T0 & $\begin{array}{c}\text { MGG_08341 | Magnaporthe } \\
\text { oryzae } 70-15 \text { hypothetical } \\
\text { protein }(250 \text { aa) }\end{array}$ & $\begin{array}{l}\text { Mediator of RNA } \\
\text { polymerase II } \\
\text { transcription } \\
\text { subunit } 7\end{array}$ & $\begin{array}{c}\text { Mediator of RNA } \\
\text { polymerase II transcription } \\
\text { subunit } 7\end{array}$ \\
\hline MGG_08699T0 & $\begin{array}{c}\text { MGG_08699 | Magnaporthe } \\
\text { oryzae } 70-15 \text { hypothetical } \\
\text { protein }(219 \text { aa) }\end{array}$ & $\begin{array}{c}\text { Nudix hydrolase } \\
\text { domain-containing } \\
\text { protein }\end{array}$ & $\begin{array}{l}\text { Nudix hydrolase domain- } \\
\text { containing protein }\end{array}$ \\
\hline MGG_08949T0 & $\begin{array}{c}\text { MGG_08949 | Magnaporthe } \\
\text { oryzae } 70-15 \text { hypothetical } \\
\text { protein }(411 \text { aa) }\end{array}$ & $\begin{array}{l}\text { Uncharacterized } \\
\text { protein }\end{array}$ & Uncharacterized protein \\
\hline MGG_10359T0 & $\begin{array}{c}\text { MGG_10359 | Magnaporthe } \\
\text { oryzae } 70-15 \text { hypothetical } \\
\text { protein (416 aa) }\end{array}$ & $\begin{array}{l}\text { Uncharacterized } \\
\text { protein }\end{array}$ & Uncharacterized protein \\
\hline MGG_10716T0 & $\begin{array}{c}\text { MGG_10716 | Magnaporthe } \\
\text { oryzae } 70-15 \text { hypothetical } \\
\text { protein (180 aa) }\end{array}$ & $\begin{array}{l}\text { Uncharacterized } \\
\text { protein }\end{array}$ & Uncharacterized protein \\
\hline MGG_11475T0 & $\begin{array}{c}\text { MGG_11475 | Magnaporthe } \\
\text { oryzae } 70-15 \text { hypothetical } \\
\text { protein }(1029 \text { aa) }\end{array}$ & $\begin{array}{l}\text { alpha-1,2- } \\
\text { Mannosidase }\end{array}$ & alpha-1,2-Mannosidase \\
\hline MGG_11761T0 & $\begin{array}{c}\text { MGG_11761 | Magnaporthe } \\
\text { oryzae } 70-15 \text { hypothetical } \\
\text { protein }(619 \text { aa) }\end{array}$ & $\begin{array}{l}\text { Uncharacterized } \\
\text { protein }\end{array}$ & Uncharacterized protein \\
\hline MGG_11907T0 & $\begin{array}{c}\text { MGG_11907 | Magnaporthe } \\
\text { oryzae } 70-15 \text { hypothetical } \\
\text { protein (461 aa) }\end{array}$ & $\begin{array}{l}\text { Myosin-like coiled- } \\
\text { coil protein }\end{array}$ & $\begin{array}{l}\text { Myosin-like coiled-coil } \\
\text { protein }\end{array}$ \\
\hline MGG_14388T0 & $\begin{array}{c}\text { MGG_14388 I Magnaporthe } \\
\text { oryzae } 70-15 \text { hypothetical } \\
\text { protein ( } 202 \text { aa) }\end{array}$ & $\begin{array}{l}\text { Uncharacterized } \\
\text { protein }\end{array}$ & Uncharacterized protein \\
\hline MGG_15612T0 & $\begin{array}{c}\text { MGG_15612 | Magnaporthe } \\
\text { oryzae } 70-15 \text { hypothetical } \\
\text { protein (1340 aa) }\end{array}$ & $\begin{array}{c}\text { Methyltransf_11 } \\
\text { domain-containing } \\
\text { protein }\end{array}$ & $\begin{array}{l}\text { Methyltransf_11 domain- } \\
\text { containing protein }\end{array}$ \\
\hline MGG_15825T0 & $\begin{array}{c}\text { MGG_15825 | Magnaporthe } \\
\text { oryzae } 70-15 \text { hypothetical } \\
\text { protein }(593 \text { aa) }\end{array}$ & $\begin{array}{l}\text { Uncharacterized } \\
\text { protein }\end{array}$ & Uncharacterized protein \\
\hline MGG_17682T0 & $\begin{array}{c}\text { MGG_17682 | Magnaporthe } \\
\text { oryzae } 70-15 \text { hypothetical } \\
\text { protein (150 aa) }\end{array}$ & $\begin{array}{c}\text { Ribonuclease H2 } \\
\text { non-catalytic } \\
\text { subunit }\end{array}$ & $\begin{array}{l}\text { Ribonuclease } \mathrm{H} 2 \text { non- } \\
\text { catalytic subunit }\end{array}$ \\
\hline
\end{tabular}

DUF - Domain of Unknown Function

\section{LITERATURE CITED}

(1) El-Gebali, S.; Mistry, J.; Bateman, A.; Eddy, S. R.; Luciani, A.; Potter, S. C.; Qureshi, M.; Richardson, L. J.; Salazar, G. A.; Smart, A.; Sonnhammer, E. L. L.; Hirsh, L.; Paladin, L.; Piovesan, D.; Tosatto, S. C. E.; Finn, R. D. The Pfam Protein Families Database in 2019. Nucleic Acids Res. 2018, 47, 427-432. https://doi.org/10.1093/nar/gky995. 